\title{
Biomassa in Zuid Holland circulair verwaarden
}

$\begin{array}{ll}\text { Auteurs: } & \text { Wolter Elbersen (Wageningen Food \& Biobased Research) en Joop Groen (Biobased } \\ \text { Delta) } & \end{array}$

Onder begeleiding van Roos Marinissen en Henk de Bruin van de Omgevingsdienst Zuid-Holland Zuid.

Dit onderzoek is uitgevoerd door Wageningen Food \& Biobased Research in opdracht van Omgevingsdienst ZuidHolland Zuid en gefinancierd door Provincie Zuid Holland. 
Versie: definitief

Vertrouwelijk tot en met: oktober 2020

Reviewer: Edwin Hamoen

Goedgekeurd door: Jan Jetten

Opdrachtgever: Omgevingsdienst Zuid-Holland Zuid.

Financier: Provincie Zuid-Holland

(C) 2020 Wageningen Food \& Biobased Research, instituut binnen de rechtspersoon Stichting Wageningen Research.

Vertrouwelijk rapport. Uit deze uitgave mag niets worden gereproduceerd en/of openbaar gemaakt zonder voorafgaande schriftelijke toestemming van de directeur van Wageningen Food \& Biobased Research.

Postbus 17, 6700 AA Wageningen, T 03174800 84, E www.wur.nl/wfbr. Wageningen Food \& Biobased Research is onderdeel van Wageningen University \& Research.

Alle rechten voorbehouden. Niets uit deze uitgave mag worden verveelvoudigd, opgeslagen in een geautomatiseerd gegevensbestand of openbaar gemaakt in enige vorm of op enige wijze, hetzij elektronisch, hetzij mechanisch, door fotokopieën, opnamen of enige andere manier, zonder voorafgaande schriftelijke toestemming van de uitgever. De uitgever aanvaardt geen aansprakelijkheid voor eventuele fouten of onvolkomenheden. 


\section{Inhoud}

$1 \quad$ Inleiding $\quad 4$

2 Biomassareststromen in Zuid Holland $\quad 5$

$\begin{array}{lll}2.1 & \text { Biomassa reststromen in Zuid Holland } & 5\end{array}$

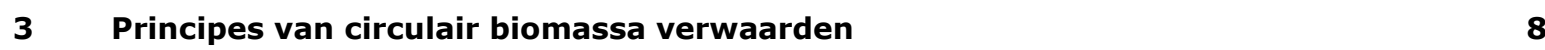

3.1 Achtergrond $r$

3.2 Verwaarden van biomassa(residuen) en afvallen $\quad 11$

4 Biomassa verwaardingsmogelijkheden in de Provincie Zuid Holland 14

4.1 Relevante biomassa reststromen en toepassingen in Zuid-Holland 15

$\begin{array}{ll}4.2 & \text { Nieuwe en innovatieve verwaardingsmethoden } \\ \end{array}$

5 Discussie en acties $r$

$\begin{array}{llr}5.1 & \text { Discussie } & 19\end{array}$

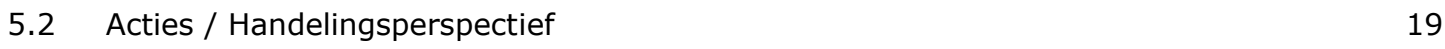

$\begin{array}{lr}\text { Literatuur } & 21\end{array}$

Bijlage 1. PowerPoint presentatie Workshop 11 mei 202022 


\section{$1 \quad$ Inleiding}

De Omgevingsdienst Zuid-Holland Zuid werkt binnen het thema Biomassa \& Voedsel aan de implementatie van het programma circulair Zuid-Holland. Biomassa speelt een belangrijke rol bij het realiseren van een toekomstbestendige energie- en grondstoffenvoorziening. Verschillende partijen ontwikkelen uiteenlopende initiatieven voor de verwerking en benutting van biomassa. Zoals het verwerken van bermgras, benutten van organische reststromen of grootschalige raffinage van biomassa in producten. Om te kunnen beoordelen welke van deze initiatieven daadwerkelijk leiden tot een duurzame productie en benutting van biomassa, is er binnen de provincie Zuid-Holland behoefte aan een afwegingskader. Dit afwegingskader zou naast technische, juridische en financiële criteria ook in duurzaamheidscriteria voor biomassa moeten voorzien. In de afgelopen jaren zijn al verschillende duurzaamheidskaders voor biomassa ontwikkeld. Deze zijn gericht op het kwantificeren van het broeikaseffecten en ecologische en sociale impacts. Betrekkelijk nieuw is de wens om biomassa zo circulair mogelijk in te zetten. Een goed kader om de circulariteit van toepassingen te vergelijken is er niet. Er is in de maatschappij discussie over de inzet van biomassa voor energie, een optie die gezien wordt als minder circulair. Mar een goed kader om de "circulariteit" van biomassa toepassingen te vergelijken is er niet.

WFBR, Biobased Delta en Avans Hogeschool zijn benaderd om bij te dragen aan het ontwikkelen van plannen die bijdragen aan het circulair verwaarden van biomassa in Zuid-Holland. Hiervoor zijn er activiteiten opgestart om de biomassastromen in Zuid-Holland in kaart te brengen (Rijkers. 2020).

WRBR is gevraagd om samen met Biobased Delta een notitie te schrijven waarin de kansen voor het verwaarden van Zuid-Hollandse biomassa-reststromen in een circulaire economie worden beschreven op basis van de biomassa-inventarisatie van Avans Hogeschool. Daarnaast is het doel van de notitie om input te leveren voor het opstellen van een principieel afwegingskader m.b.t. circulariteit en duurzaamheid voor de omgevingsdiensten en de Provincie met betrekking tot circulair verwaarden van biomassa-reststromen. Dit kader zou een rol moeten spelen bij het maken van keuzes welke verwaardings-initiateven te ondersteunen en ruimte te bieden. In de loop van het project is er input geleverd vanuit bijeenkomsten met stakeholders die biomassa bezitten en verwerken of die initiatieven ontwikkelen om biomassa circulair te verwerken ${ }^{1}$.

\footnotetext{
${ }^{1}$ De presentaties gegeven op deze bijeenkomsten door WFBR en Biobased Delta zijn opgenomen in de Bijlagen
} 


\section{Biomassareststromen in Zuid Holland}

\subsection{Biomassa reststromen in Zuid Holland}

In dit hoofdstuk beschrijven we de specifieke biomassa stromen uit het gebied Zuid Holland, gebaseerd op een analyse door Avans Hogeschool (Jasper Rijkers, 2020) aangevuld met een inschatting van de huidige toepassingen.

Tabel 1. geeft het overzicht van de Avans Hogeschool analyse van de biomassa stromen in Zuid Holland. Op basis van de hoeveelheden zijn met afstand de grootse biomassa stromen mest (3900 kton/jaar), biologisch afbreekbaar afval (1045 kton) en voor consumptie of verwerking ongeschikt materiaal (916 kton). Deze volumes zijn als vers gewicht gepresenteerd, dus inclusief water. Deze top 3 vertegenwoordigd met 5861 kton $78 \%$ van de totale stroom. Het is belangrijk te beseffen dat de volumes van deze stromen groot zijn maar het droge stof gehalte is relatief laag is. Dit wordt in Tabel 1 kort beschreven.

Om een meer diepgaande analyse te maken zouden 2 zaken prioriteit behoeven:

- Compositie eigenschappen van de stromen (droge stof, anorganisch, hemicellulose, cellulose, lignine, eiwitten, nutriënten, etc.). Op basis hiervan is het beter mogelijk om de bijbehorende verwerkingsprocessen en logistieke ketens in te schatten. Zeker wanneer de tactiek van het behoud van functionaliteit gevolgd wordt (zie hoofdstuk 3 ) is het belangrijk de functionele componenten te kennen.

- Van enkele stromen is een meer gedetailleerde analyse nodig, bijvoorbeeld wat zit er in de categorie "voor consumptie en verwerking ongeschikt materiaal". Ook de relatief kleinere stromen kunnen belangrijk zijn, vooral indien hiervoor kansrijke specifieke toepassingen gerealiseerd kunnen worden, denk aan sinaasappel schillen of koffie residuen.

Van een aantal stromen (bijvoorbeeld mest) is in principe veel detail informatie per gemeente en type biomassa (bijvoorbeeld, dunne en dikke mest) beschikbaar (zie Tabel 10 in Rijkers, 2020).

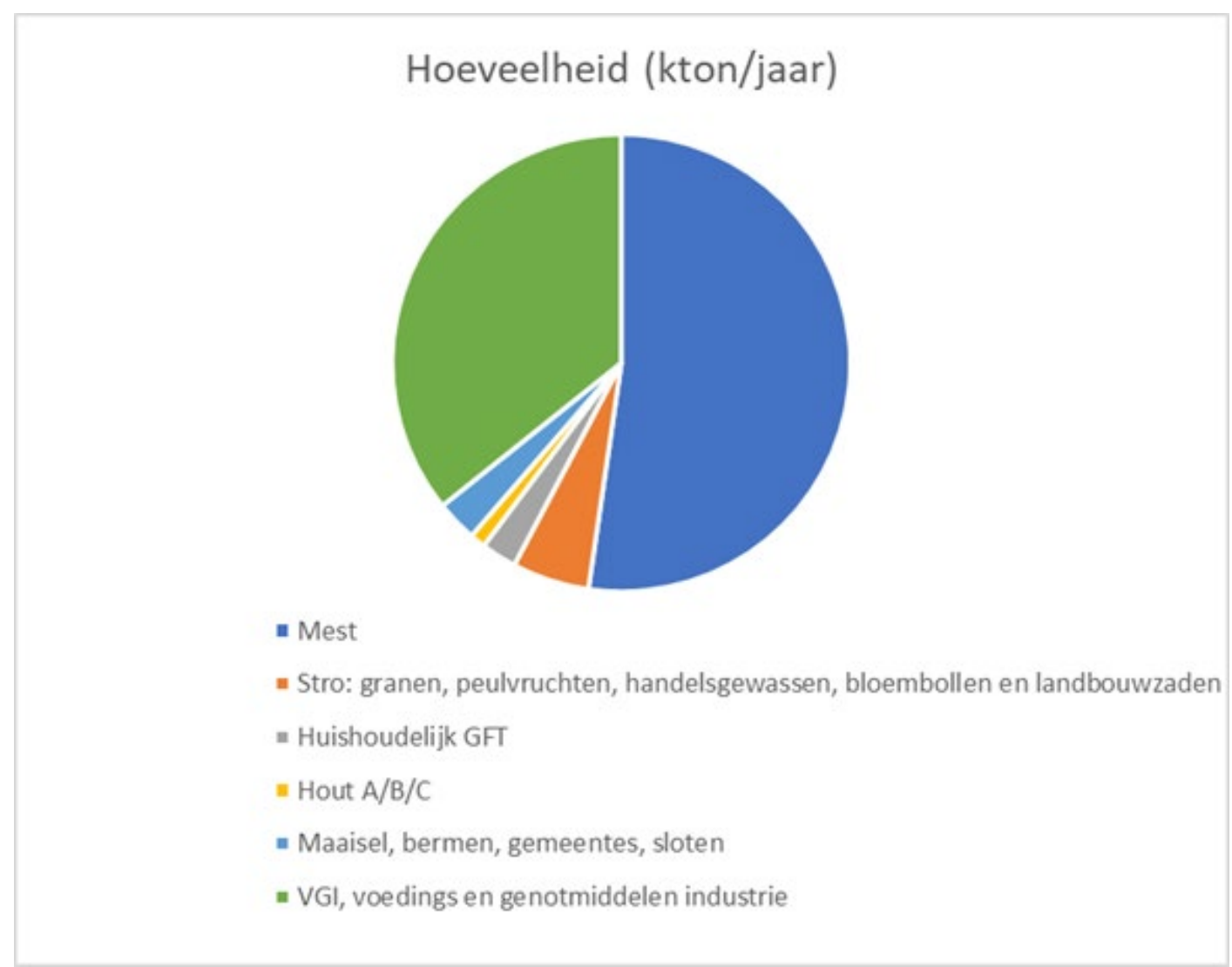

Figuur 1 Volumes (vers gewicht) van biomassa in Zuid Holland. 
Tabel 1

Biomassa stromen in Zuid Holland zoals in kaart gebracht in een studie door

Avans (Jasper Rijkers, 2020). De kwaliteit van de stromen is door de auteurs ingeschat op basis van beschikbare informatie.

\begin{tabular}{|c|c|c|c|}
\hline Stromen: & $\begin{array}{l}\text { Hoeveelheid } \\
\text { (kton/jaar vers) }\end{array}$ & Kwaliteit & Huidige toepassing \\
\hline \multicolumn{4}{|l|}{ GFT } \\
\hline Huishoudelijk GFT & 187 & $\begin{array}{l}\text { Groen -Fruit en Tuinafval, } \\
\text { zeer variabel. In Groen en } \\
\text { tuinafval zullen ook veel } \\
\text { nutriënten zitten ( } N, P, K) \text {. } \\
\text { Eiwitgehalte zal ook } \\
\text { relevant kunnen zijn, maar } \\
\text { moeilijk te verwaarden. }\end{array}$ & $\begin{array}{l}\text { Scheiding, Compostering na afscheiding van } \\
\text { plastic en ander afval, soms voorafgaand } \\
\text { door vergisting. }\end{array}$ \\
\hline \multicolumn{4}{|l|}{ Agrarische reststromen } \\
\hline $\begin{array}{l}\text { Stro van granen, peulvruchten, } \\
\text { handelsgewassen en landbouwzaden }\end{array}$ & 326 & $\begin{array}{l}\text { Stro en loof. Van sommige } \\
\text { stromen zoals bietenloof } \\
\text { kan nutriëntengehalte } \\
\text { eiwitgehalte hoog genoeg } \\
\text { zijn om te verwaarden. }\end{array}$ & $\begin{array}{l}\text { Onderploegen (bodemverbetering), stro } \\
\text { vaak verkocht voor stallen / } \\
\text { bodembedekken, etc. }\end{array}$ \\
\hline $\begin{array}{l}\text { Snoei/rooi hout uit de fruitsector en } \\
\text { boomkwekerij }\end{array}$ & 16 & $\begin{array}{l}\text { Houtige biomassa met een } \\
\text { iets hoger as gehalte dan } \\
\text { schoon hout. Afvoer is vaak } \\
\text { gewenst om ziekten te } \\
\text { voorkomen }\end{array}$ & $\begin{array}{l}\text { Houttoepassingen, energie, soms op veld } \\
\text { verbrand }\end{array}$ \\
\hline Reststromen uit de bloembollensector & 80 & "pellen", zand & Naar bodem soms eerst gecomposteerd \\
\hline Mest & 3900 & $\begin{array}{l}\text { Voornamelijk } \\
\text { rundveedrijfmest. Met een } \\
\text { hoog }(90 \%) \text { vocht gehalte } \\
\text { Zie www.nutrinorm.nl voor } \\
\text { samenstelling }{ }^{2}\end{array}$ & $\begin{array}{l}\text { Uitrijden op eigen land - er is weinig tot } \\
\text { geen mestvergisting of mestverwerking. In } \\
\text { ZH vooral koeienmest. Vrijwel alle mest } \\
\text { wordt lokaal toepast. Zie tabel } 10 \text { in Rijkers } \\
2020 \text {. }\end{array}$ \\
\hline \multicolumn{4}{|l|}{ Hout } \\
\hline A/B hout uit huishoudens & 75 & $\begin{array}{l}\text { Niet geïmpregneerd hout en } \\
\text { onbehandeld hout }\end{array}$ & Voornamelijk energie \\
\hline C hout uit huishoudens & 7.2 & Geïmpregneerd hout & $\begin{array}{l}\text { Voornamelijk energie in geschikte } \\
\text { installaties. Hergebruik onduidelijk }\end{array}$ \\
\hline Hout uit (natuur)landschap & $?$ & $\begin{array}{l}\text { Houtige biomassa } \\
\text { (stronken, takken etc.) }\end{array}$ & $\begin{array}{l}\text { chips, voor energie of bodembedekking. } \\
\text { Soms ook achtergelaten - heeft waarde } \\
\text { voor biodiversiteit. }\end{array}$ \\
\hline \multicolumn{4}{|r|}{ 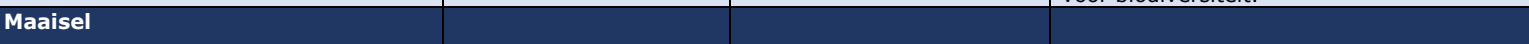 } \\
\hline Bermgras & 46 & Bermgras & $\begin{array}{l}\text { Vaak achtergelaten of afgevoerd naar } \\
\text { compostering - Soms gebruikt voor } \\
\text { vergisting }\end{array}$ \\
\hline Gemeentelijk groenafval & 76 & $\begin{array}{l}\text { Plantaardige afvalstoffen } \\
\text { van onderhoud openbaar } \\
\text { groen (parken, } \\
\text { watergangen, bos-en } \\
\text { natuurterreinen). Dit afval } \\
\text { bestaat o.a. uit takken, } \\
\text { snoeihout, bermmaaisel } \\
\text { veegafval - vaak met veel } \\
\text { zand }\end{array}$ & $\begin{array}{l}\text { Compostering. Hout ook voor energiechips } \\
\text { of als bodembedekking. }\end{array}$ \\
\hline Slootmaaisel & 95 & $\begin{array}{l}\text { Waterplanten, riet, zand en } \\
\text { slib }\end{array}$ & Op de kant gelegd \\
\hline Natuurgras & $?$ & $\begin{array}{l}\text { Gemaaid natuurgras, vaak } \\
\text { vervuild met zand }\end{array}$ & $\begin{array}{l}\text { Soms voor veevoer of als mulch of } \\
\text { bodembedekking gebruikt, ook vaak } \\
\text { achtergelaten na maaien }\end{array}$ \\
\hline \multicolumn{4}{|l|}{$\begin{array}{l}\text { VGI (voedings- en } \\
\text { genotmiddelenindustrie) }\end{array}$} \\
\hline Afval van de bosbouw & 15 & Tak en top-hout & $\begin{array}{l}\text { Achtergelaten in bos of afgevoerd als chips } \\
\text { voor energie of andere toepassingen }\end{array}$ \\
\hline Afval van plantaardige weefsels & 347 & $?$ & Onduidelijk \\
\hline $\begin{array}{l}\text { Afval van wassen, schoonmaken en } \\
\text { mechanische bewerking van de } \\
\text { grondstoffen }\end{array}$ & 11 & $?$ & Onduidelijk \\
\hline Biologisch afbreekbaar afval & 1045 & $?$ & Onduidelijk \\
\hline $\begin{array}{l}\text { Slib van afvalwaterbehandelingen ter } \\
\text { plaatse }\end{array}$ & 213 & $?$ & Onduidelijk \\
\hline Slib van wassen en schoonmaken & 14 & $?$ & Onduidelijk \\
\hline $\begin{array}{l}\text { Slib van wassen en schoonmaken, } \\
\text { pellen, centrifugeren en scheiden }\end{array}$ & 15 & $?$ & Onduidelijk \\
\hline Spijsolie en -vetten & 89 & ?bleekaarde? & Energieproductie? \\
\hline $\begin{array}{l}\text { Voor consumptie of verwerking } \\
\text { ongeschikt materiaal }\end{array}$ & 916 & $?$ & Onduidelijk \\
\hline
\end{tabular}

\footnotetext{
${ }^{2}$ https://www.nutrinorm.nl/nl-nl/Paginas/Organische-meststoffen-De-samenstelling-van-organische-meststoffen.aspx
} 
In de huidige situatie worden de biomassa stromen hoofdzakelijk als mest uitgereden over het land, achter gelaten, gecomposteerd vergist, en/of voor energie productie ingezet. Deze methoden zijn historisch gegroeid op basis van economische, logistieke en praktische afwegingen. Door het voortschrijden van zowel milieutechnische- als verwerking technische inzichten is hier veel ruimte voor verbetering. In hoofdstuk 4 wordt dieper ingegaan op de zienswijze voor verwaarding alsmede de verwerkingstechnologieën en concrete voorbeelden die relevant zijn voor de Provincie Zuid Holland. 


\section{$3 \quad$ Principes van circulair biomassa verwaarden}

\section{$3.1 \quad$ Achtergrond}

Een circulaire economie is gebaseerd op het principe dat systemen zo worden ontworpen dat afval en vervuiling niet meer bestaan en producten en materialen in het systeem behouden blijven en natuurlijke systemen geregenereerd worden (naar de Ellen McArthur foundation).

Het doel is dus om grondstoffen zo efficiënt mogelijk te benutten en zo lang mogelijk in het systeem te houden. In Figuur 2 is dat weergegeven in 9 strategieën gericht op efficiënt benutten, tegengaan van verspilling, en als er residuen ontstaan deze zo hoogwaardig mogelijk in te zetten. In die zin is de circulaire economie een verdere uitwerking van bestaande vuistregels voor het verwaarden van biomassa-afval. Zie de waarde piramide en de ladder van Moerman in Figuur 3 (overgenomen uit PBL. 2018).

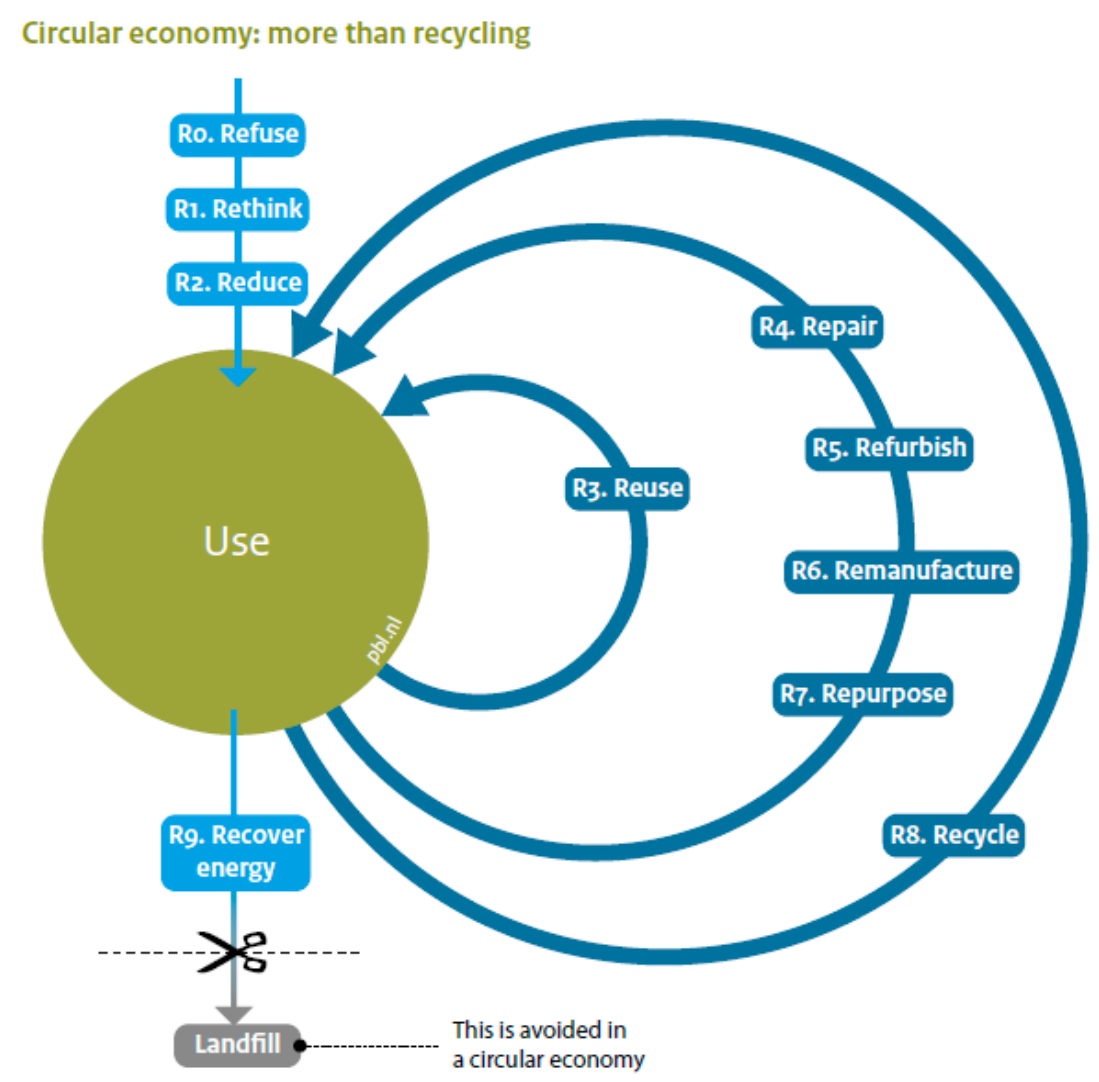

Source: PBL

Figuur 2 R ladder met 9 strategieën van circulariteit overgenomen van PBL (p11, PBL 2018)

Daarbij heeft de toepassing van biomassa ook als doel het vervangen van niet hernieuwbare door wel hernieuwbare grondstoffen, biomassa. Wanneer fossiele en andere niet-hernieuwbare grondstoffen worden vervangen door hernieuwbare bronnen (zoals biomassa en biomassa reststromen) kan dit een aanzienlijke CO2-reductie betekenen (p 9 Min I\&M. 2019). 


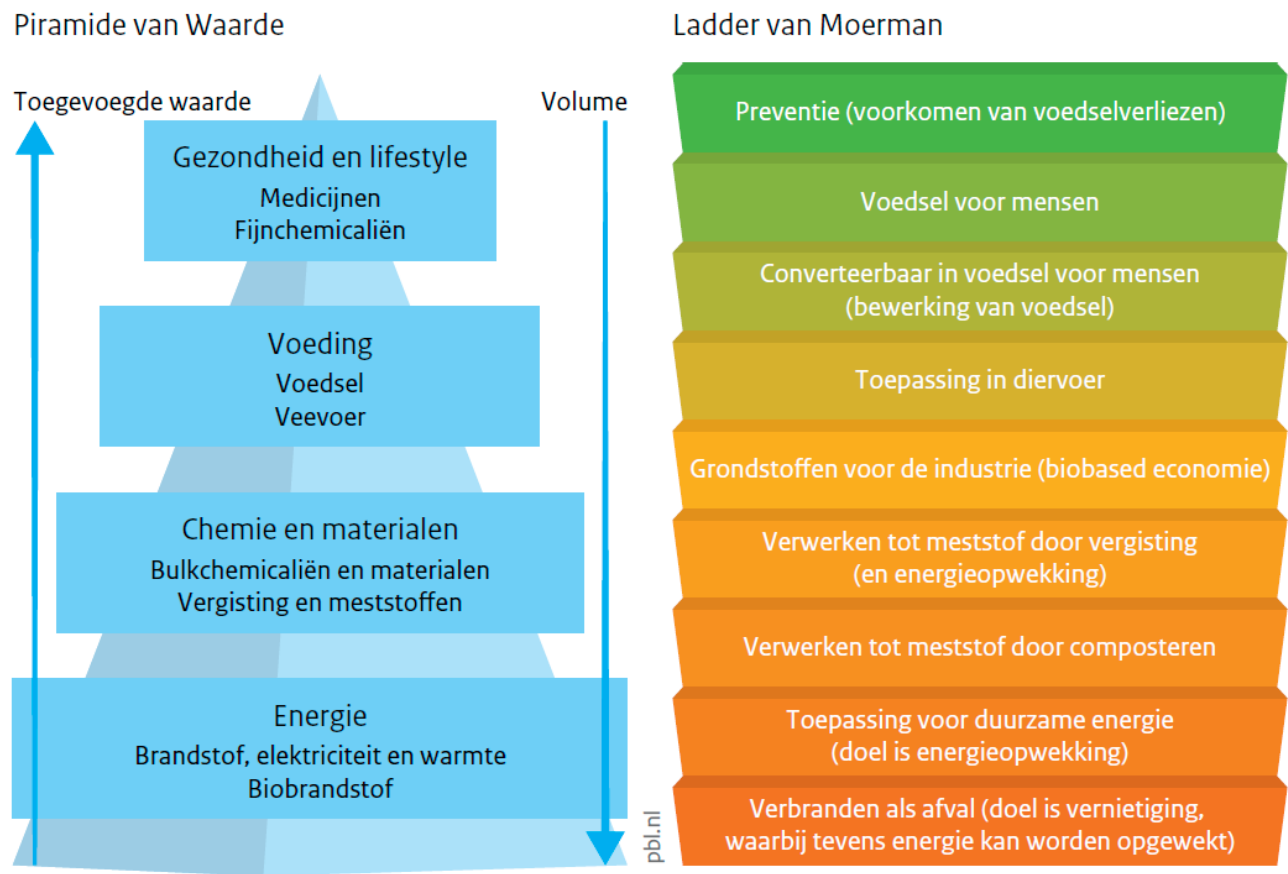

Bron: PBL

Figuur 3 De biomassa waarde piramide en de ladder van Moerman geven vuistregels voor het beslissen over hoogwaardige toepassingen van biomassa (p33, PBL 2016)

\section{Biomassa is anders}

Biomassa is anders dan gewone grondstoffen. Biomassa is van zichzelf bijna geheel circulair. Tenslotte leggen planten $\mathrm{CO} 2$ vast die bij benutting van de biomassa uiteindelijke weer $\mathrm{CO} 2$ wordt als het afbreekt of verbrand wordt. Dit kan eindeloos doorgaan. Wel hebben planten meststoffen/nutrieten nodig waaronder fosfaat en kalium, grondstoffen waarvan de makkelijk beschikbare voorraden op kunnen raken. Verder is er bemesting nodig met stikstof wat weliswaar net als CO2 hernieuwbaar is, het raakt niet op, maar waarvan de productie (vastlegging) veel energie vraagt en ook broeikasgasuitstoot in de vorm van $\mathrm{CO}_{2}$ en $\mathrm{N}_{2} \mathrm{O}$ (lachgas) met zich meebrengt. Voor productie van biomassa is tevens land en water nodig die vaak schaars zijn. Productie van biomassa kost energie, zowel tijdens productie, verwerking als vervoer.

Er zijn toepassingen van biomassa waarbij de biomassa verloren gaat zoals bij verbranding. Andere toepassingen zoals meubels of veevoer gebruiken wel biomassa maar verbruiken het niet of maar gedeeltelijk (veevoer wordt voor een deel omgezet in mest, melk en vlees). Verder zijn er toepassingen die meer toegevoegde waarde leveren en toepassingen die een eindstation vormen voor de biomassa (de biomassa wordt afgebroken tot $\mathrm{CO} 2$, zoals bij verbranden of verteren) en dus zo lang mogelijk uitgesteld moeten worden. Op deze wijze kan $\mathrm{CO} 2$ ook lang vastgelegd worden.

Dit is de gedachte achter de biomassa waardepiramide en de ladder van Moerman (Figuur 3). In het concept van de R strategieën (Figuur 2) is er voor biomassa daarom door PBL (2019) een hiërarchie gemaakt van toepassingen (geredeneerd vanuit biomassa voor voedsel) (Figuur 4). Daarbij is er een voorkeur voor het weer inzetten van bijproducten als voedsel en veevoer, vervolgens als grondstof voor de industrie (materialen, chemie, etc.), dan als meststof of compost en dan voor energie en het voorkomen dat de biomassa af wordt gezet zonder enige benutting (storten of verbranden zonder energie benutting). 


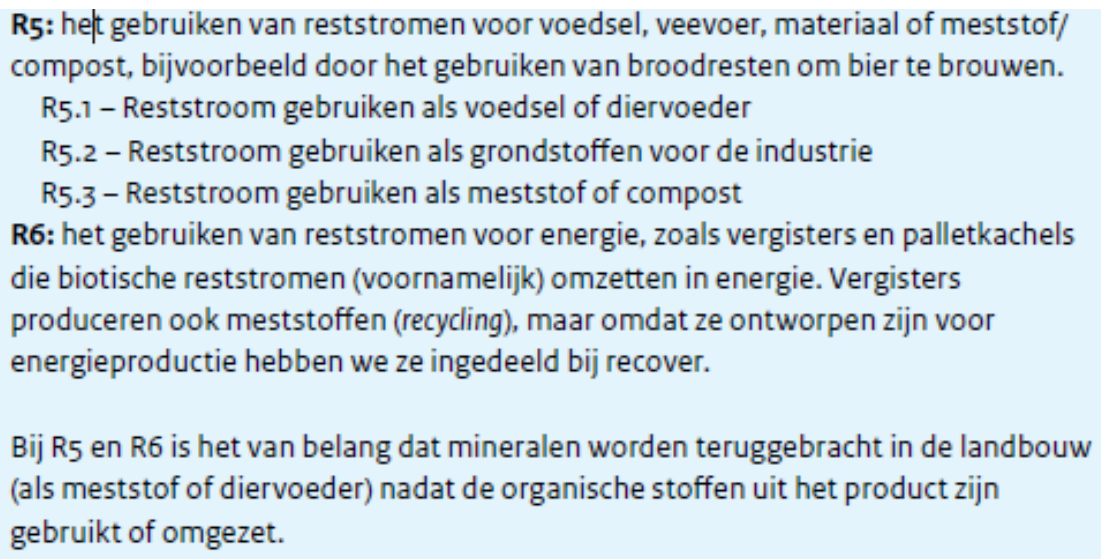

Bij R5 en R6 is het van belang dat mineralen worden teruggebracht in de landbouw (als meststof of diervoeder) nadat de organische stoffen uit het product zijn gebruikt of omgezet.

\section{Figuur 4 Specifieke sub- R-trappen voor biomassa (p25, PBL 2019)}

Zoals in de PBL rapporten ook aangegeven bieden deze voorkeurs-hiërarchieën goede handvatten maar ze verdisconteren geen andere aspecten zoals de efficiëntie en het feit dat biomassa uit verschillende functionele onderdelen (chemisch en fysisch) bestaat in sterk wisselende hoeveelheden.

Alle biomassa bestaan uit :

- Vezels (bestaande uit lignine, cellulose, hemicellulose)

- Eiwitten

- Koolhydraten (suikers en zetmeel)

- Vetten

- Mineralen/nutriënten ( $N, P, K)$

- Specifieke moleculen (antioxidanten, kleurstoffen, geurstoffen, etc.)

Dat maakt dat je eigenlijk per onderdeel van de biomassa (vezel, eiwit, oliën en vetten, etc.) trappen zou moeten maken voor "hoogwaardigheid" en dat je ook de efficiëntie en de impact van die toepassingen mee zou moeten nemen.

Elbersen et al (2020) geeft een aanzet tot het ontwikkelen van dit soort indicatoren, redenerend vanuit het benutten van de functionaliteit van de biomassa (onderdelen), de efficiëntie van die inzet en de mogelijkheid om het daarna weer te benutten en op welk niveau.

Zo kun je voor hout(vezels) komen tot vijf trappen van functionaliteit (Spijker et al., 2020):

4. Houttoepassing (meubels, bouwen, klompen)

3. Vezeltoepassing (papier/pulp, stalstrooisel)

2. Monomeren/moleculen (chemicaliën, fuels)

1. Energie (warmte en elektriciteit)

0 . Verbranden zonder energiebenutting

Als je dan ook efficiëntie van benutting meeneemt en de mogelijkheid om de biomassa te herbenutten kun je scores produceren zoals in Tabel 3. Dit laat zien dat hout/biomassa gecascadeerd wordt waarbij een deel hoogwaardig wordt ingezet en een rest iets "laagwaardiger" wordt ingezet.

Er kan dan een samengestelde score voor deze indicator berekend worden:

$70 \%$ van het hout wordt pulp dat een functionaliteit heeft van 3 . En de overige $30 \%$ wordt in energie omgezet (functionaliteit 1 ) met een efficiëntie van $80 \%$. De score is dan $(3 \times 0.7)+(1 \times 0.3 \times 0.8)=$ $2.1+0.24=2.34$ als indicator voor de circulariteit van de benutting. Daarnaast is het mogelijk om ook het papier te herbenutten op een zelfde niveau van 3 . Dis $70 \% \times 3=2.1$. Het hout voor energie $(30 \%)$ is niet herbruikbaar. 


\begin{tabular}{|c|c|c|c|c|}
\hline Toepassing & $\begin{array}{l}\text { Functionaliteit } \\
\text { (0 tot } 4)\end{array}$ & $\begin{array}{l}\text { Materiaal- } \\
\text { efficiëntie }\end{array}$ & $\begin{array}{l}\text { Energie- } \\
\text { efficiëntie }\end{array}$ & Score \\
\hline Papierpulp uit hout (70\%) & 3 & $70 \%$ & & \\
\hline $\begin{array}{l}\text { Resten }(30 \%) \text { als energiehout in } \\
\text { industriële kachel met } \mathbf{8 0 \%} \\
\text { efficiëntie }\end{array}$ & 1 & $30 \%$ & $80 \%$ & \\
\hline
\end{tabular}

Analoog kan er een zelfde op functionaliteit gebaseerde hiërarchie worden gemaakt voor eiwitten (dit is slechts een aanzet):

4. Eiwit voor voedsel

3. Eiwit voor veevoer en voor non-food

2. Eiwit voor bemesting

1. Eiwit voor energie

0 . Eiwit afgebroken en niet benut.

Alle biomassa bevat ook mineralen / nutriënten die essentieel zijn voor planten. De belangrijkste zijn $\mathrm{N}$ (stikstof), $\mathrm{P}$ (fosfaat) en $\mathrm{K}$ (kalium).

Stikstof is de belangrijkste component van eiwitten en volgt min of meer de "hiërarchie" van eiwit (zie hierboven).

Het kost veel energie om $\mathrm{N}$ vast te leggen en $\mathrm{N}$ heeft een belangrijke functie als meststof in planten waar het een onderdeel van eiwitten vormt. De ontsnapping van $\mathrm{N}$ in de vorm van ammoniak of nitraat leidt tot milieuproblemen zoals bodemverzuring en eutrofiëring. Bij verwerking van mest en sommige andere residuen is het dan ook belangrijk de $\mathrm{N}$ uiteindelijk als meststof in de landbouw en dus in planten terug te voeren en niet te laten ontsnappen naar de omgeving.

$\mathrm{P}$ en $\mathrm{K}$ zijn mineralen die in de plant een belangrijk functie hebben. Levend plantenweefsel bestaat altijd voor ongeveer $1 \%$ uit $\mathrm{K}$ en $0.1 \%$ uit $\mathrm{P}$. Net als bij $\mathrm{N}$ leidt uitstoot naar de omgeving van $\mathrm{P}$ tot eutrofiering. Net als bij $\mathrm{N}$ moet $\mathrm{P}$ en $(\mathrm{K})$ in de plant terecht komen en niet in de omgeving. Aangezien er in Nederland een overschot aan P is, bestaan er initiatieven om P uit mest in het buitenland af te zetten.

$\mathrm{K}$ is minder waardevol en kost minder om te winnen dan $\mathrm{P}$, verder geldt dezelfde logica als bij $\mathrm{P}$. Inzetten als efficiënte meststof en niet laten ontsnappen naar de omgeving.

Net als $\mathrm{N}$ zijn $\mathrm{P}$ en $\mathrm{K}$ ook belangrijke componenten van voedsel en veevoer. Als er hier ook een hiërarchie bedacht zou moeten worden zou voedsel en veevoer en wellicht materialen boven inzet als meststof komen. Bij verbranding of vergisting leveren $\mathrm{K}$ en $\mathrm{P}$ geen energie maar kunnen wel weer teruggewonnen worden uit digestaat na vergisting of teruggewonnen worden uit as na verbranding. As wordt vaak voor wegenbouw gebruikt het gaat dan verloren als meststof. Ook als de as gestort wordt gaat het als meststof verloren.

De hierboven voorstelde hiërarchieën voor componenten van biomassa zijn een aanzet die nog verder uitgewerkt zou moeten worden.

\subsection{Verwaarden van biomassa(residuen) en afvallen}

Bij het verwaarden van biomassa (residuen) en afval is, zoals hierboven beschreven, efficiënt circulair inzetten belangrijk. Andere beoordelingsaspecten zullen echter ook meegewogen moeten worden zoals hieronder besproken worden. In Figuur 5 wordt een afwegingskader gepresenteerd in de vorm van een spiderdiagram dat relatieve scores (bijvoorbeeld nieuwe toepassing vs. huidige toepassing) weer kan geven voor biomassatoepassingen. Er zijn hiervoor 4 domeinen gekozen (Socio-economische impact, Milieu- en Ecologische impact; Circulariteit en Implementeerbaarheid) waarbinnen scores voor indicatoren gegeven kunnen worden:

- Het socio-economische domein: hier worden indicatoren opgenomen zoals de financiële haalbaarheid, toegevoegde waarde, banen, etc. 
- $\quad$ Milieu en Ecologische domein: Hieronder vallen o.a. het broeikaseffect, effect op de bodem, luchtkwaliteit en waterkwaliteit

- Circulaire domein: Hier vallen de bovengenoemde indicatoren per biomassacomponent: Benutting van de functionaliteit maal efficiëntie; Herbruikbaarheid maal efficiëntie plus, indien relevant, het effect op landgebruik efficiëntie.

- Implementatie-domein: Hieronder vallen de aanwezigheid van regels zoals certificering, normen, subsidiesystemen, etc.; De aansluiting op beleid (nu en in de toekomst); de aanwezigheid van infrastructuur; en de beschikbaarheid van kennis en technologie.

De indicatoren in de Socio-Economische en Milieu domeinen zijn al bekend en de weging kan aangepast worden aan de lokale prioriteiten.

De Circulaire indicatoren zijn nog in ontwikkeling, maar de aanzet hierboven geeft al wel houvast om toepassingen van biomassa met elkaar te vergelijken.

In het laatste domein "Implementeerbaarheid" hebben overheden de meeste invloed. Regels kunnen aangepast worden, subsidies kunnen worden gegeven of ontwikkeling van kennis en techniek kan worden ondersteund. Het beschreven afwegingskader kan verder worden uitgewerkt tot een systeem dat past bij de lokale situatie. Hierbij kunnen de indicatoren specifieke wegingen krijgen die de lokale prioriteiten weergeven.

De casus "Eiwit uit bietenblad en vergisting van de resten" is weergegeven in Tabel 3 en Figuur 5. De scores zijn ingeschat (met expert judgement) vergeleken met de bestaande situatie. In deze casus wordt bietenblad geoogst in plaats van achtergelaten op het veld. Eiwit wordt er uit geraffineerd en de resten worden vergist voor energieproductie. Dit proces wordt door Cosun geïmplementeerd (www.cosunbeetcompany.nl) en o.a. door WFBR verder ontwikkeld voor ook andere groene reststromen ${ }^{3}$. Het digestaat wordt terug gebracht naar het veld.

Tabel 3 Voorbeeld van een berekening van een samengestelde indicator voor de hoogwaardigheid voor toepassingen suikerbieten blad dat op het veld achtergelaten kan worden vs. afvoeren van het blad voor productie van eiwitten voor humane consumptie. De rest wordt vergist voor energie en het residu naar het land gebracht als meststof (naar Elbersen et al 2020). Scores lopen van -2

tot +2 .

\begin{tabular}{|c|c|c|c|}
\hline & Achterlaten & $\begin{array}{l}\text { Bioraffineren } \\
\text { en vergisten }\end{array}$ & Uitleg \\
\hline Mogelijkheid hergebruik & 0 & 1 & $\begin{array}{l}\text { Eiwit kan als eiwit weer benut worden of al meststof / } \\
\text { massa kan als meststof benut worden }\end{array}$ \\
\hline Land besparing & 0 & 1 & Minder soja telen \\
\hline Broeikaseffect & 0 & 1 & Fossiel gas vermeden \\
\hline Bodemkwaliteit & 0 & 0 & $\begin{array}{l}\text { Vermoedelijk na vergisting zelfde waarde als } \\
\text { achterlaten }\end{array}$ \\
\hline Biodiversiteit & 0 & 0 & onbekend \\
\hline Waterkwaliteit & 0 & 1 & Geen uitspoeling nutriënten in winter \\
\hline Technologie beschikbaar & 0 & -1 & eiwit extractie nog in ontwikkeling / \\
\hline Infrastructuur beschikbaar & 0 & -1 & Eiwit en biogas installatie moeten gebouwd worden \\
\hline Beleidsondersteuning & 0 & 1 & Beleid steunt onderzoek \\
\hline $\begin{array}{l}\text { Regels, standaarden, } \\
\text { subsidies, etc. }\end{array}$ & 0 & -1 & $\begin{array}{l}\text { Weggehaalde nutriënten mogen niet aangevuld } \\
\text { worden / boer verliest nutriënten = Mineralen } \\
\text { boekhouding }\end{array}$ \\
\hline Toegevoegde waarde & 0 & 1 & Extra waarde eiwit en waarde biogas \\
\hline Goede business case & 0 & 1 & Lijkt nu van de grond te komen \\
\hline Banen & 0 & 1 & Meer bedrijvigheid \\
\hline
\end{tabular}

\footnotetext{
${ }^{3}$ https://www.nieuweoogst.nl/nieuws/2019/10/11/eiwit-uit-bietenblad-als-voedingsingredient
} 


\begin{tabular}{|c|c|c|c|}
\hline Lokale ontwikkeling & 0 & 1 & Lokaal \\
\hline Hoogwaardigheid inzet & 0 & 2 & Eiwit als eiwit ingezet / biogas potentie benut \\
\hline $\begin{array}{l}\text { Efficiëntie van biomassa } \\
\text { gebruik }\end{array}$ & 0 & 1 & $\begin{array}{l}\text { Bij bodemtoepassing eiwit laagwaardiger benut en } \\
\text { biogas niet benut }\end{array}$ \\
\hline
\end{tabular}

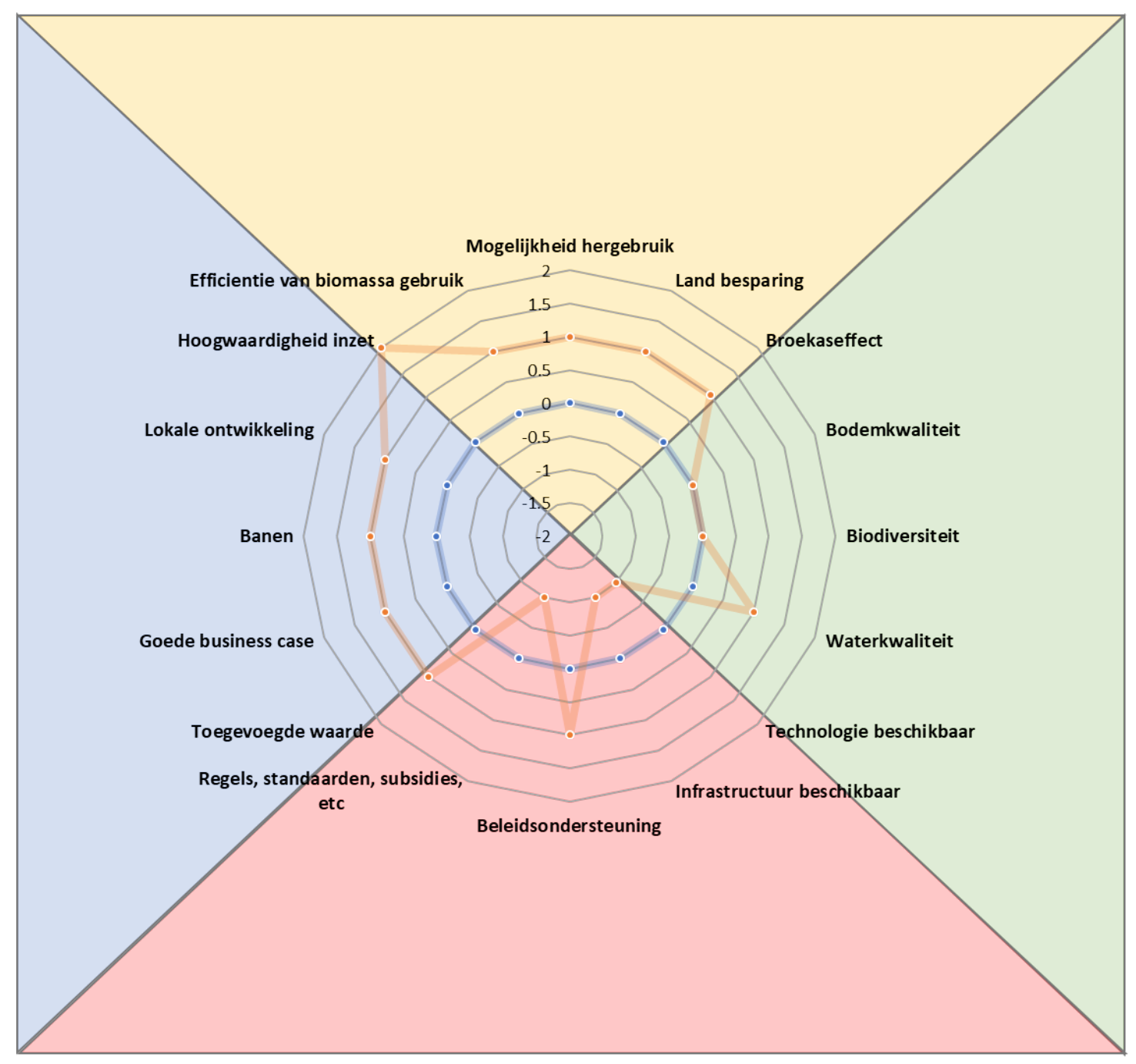

Figuur 5 Spiderdiagram warin de beoordelingsfactoren voor toepassing van suikerbietblad voor eiwitraffinage en vergisting van de residuen is weergegeven. De vergelijking is gescoord t.o.v. de bestaande situatie. 


\section{Biomassa verwaardingsmogelijkheden in de Provincie Zuid Holland}

In dit hoofdstuk behandelen we verwaardingsmogelijkheden van de voornaamste in Hoofdstuk 2 genoemde stromen. Hierbij worden een aantal voorbeelden gegeven van nieuwe technologieën en initiatieven die een rol kunnen spelen om deze stomen te verwaarden. Figuren 6 en 7 hieronder geven een overzicht van een aantal van de mogelijkheden in de richting van chemicaliën en brandstoffen.

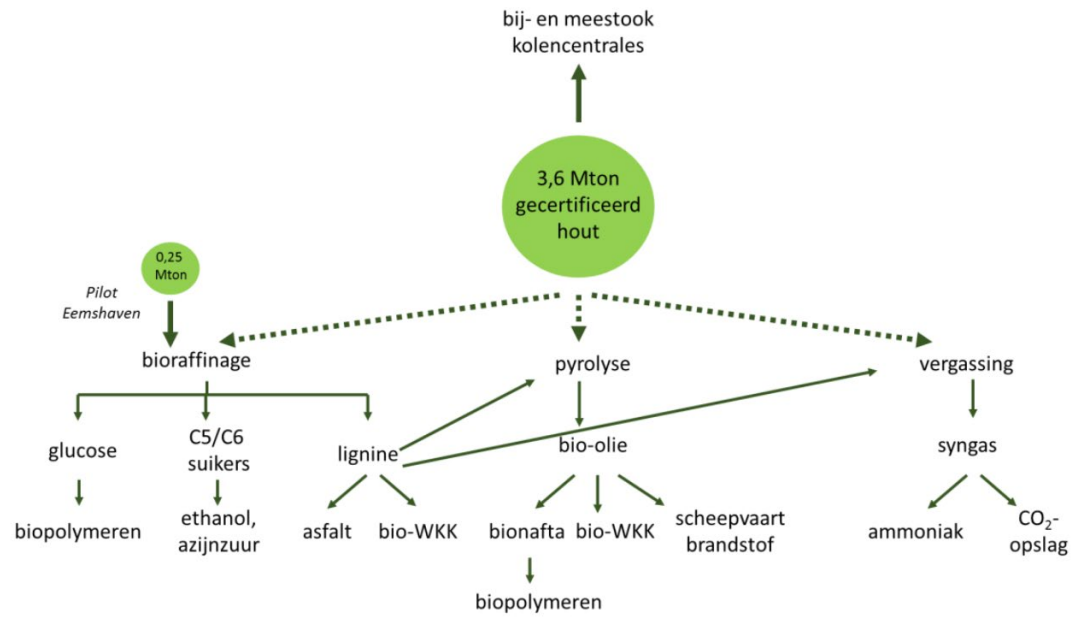

Figuur 6 Voorbeeld van hout verwaarding uit routekaart biomassa cascadering (WKK = WarmteKrachtKoppeling)

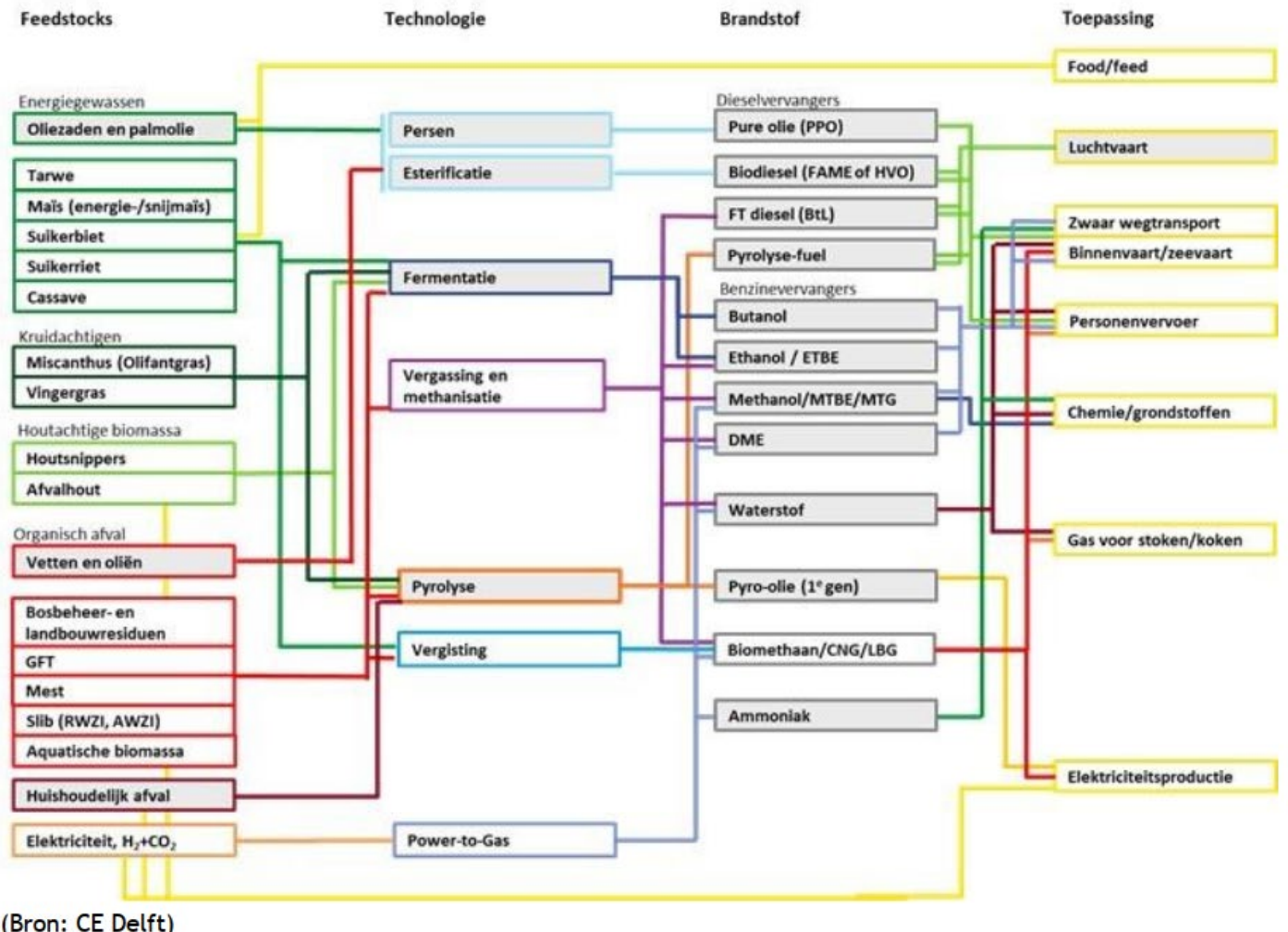

Figuur $7 \quad$ Voorbeeld inzet biomassa met focus op biobrandstoffen uit Bio-Scope verslag CE Delft 


\subsection{Relevante biomassa reststromen en toepassingen in Zuid-Holland}

\section{Mest}

In Zuid-Holland is er geen mestoverschot. De meeste mest is koeienmest die op eigen land uitgereden kan worden. Wel is het zo dat er vanuit circulair oogpunt nog veel te halen valt. Mest wordt nu opgeslagen op de boerderij waarbij methaan en ammoniak ontsnapt met name als de mest vers is. Het voorkomen dat methaan en ammoniak in de atmosfeer ontsnappen is steeds belangrijker. Meteen vergisten of mest aanzuren zodat er geen methaan ontstaat, zijn opties. Verder worden er technologieën ontwikkeld en geïmplementeerd om mest te verwerken. Deze kunnen gericht zijn op scheiding in vaste en vloeibare fractie. De vaste fractie bevat meer $\mathrm{P}$ dan de vloeibare fractie waardoor het mogelijk is optimaal $\mathrm{N}$ en $\mathrm{P}$ in de mest te doseren ${ }^{4}$. $\mathrm{P}$ kan dan als meststof worden gewonnen. Hiernaar wordt bijvoorbeeld onderzoek gedaan door WUR ${ }^{5}$. De P meststof kan dan bijvoorbeeld ingezet worden in kassen waar dierlijke mest nu niet wordt toegepast. Omgevingsdienst ZHZ heeft voor de landbouwsubregio Hoeksche Waard een procesvoorstel voor de geïmporteerde mest opgesteld (de Bruin 2015).

Een andere innovatieve technologie is het Bareau proces dat hieronder wordt besproken.

\section{Gewasresten: Stro van granen, peulvruchten, handelsgewassen, bloembollen en landbouwzaden}

Deze stromen worden meestal op het veld achtergelaten om bodem organische stof te verhogen of op peil te houden en de nutriënten weer terug te brengen, hoewel met name op zandgronden de oplosbare nutriënten ( $\mathrm{K}$ en $\mathrm{N}$ ) uit zullen spoelen. De samenstelling van deze stromen bepaalt welke alternatieve toepassingen mogelijk zijn. Tarwestro en graszaadstro wordt meestal verhandeld. Er bestaat een uitgebreide markt en vele toepassingen zoals in de bollenteelt en als strooisel onder paarden. Het terugbrengen van organisch materiaal is belangrijk voor de bodem en krijgt steeds meer aandacht. Geredeneerd vanuit circulariteit zou dat systeem wel beter kunnen: Gewasresten kunnen ook verwijderd worden en na vergisting als digestaat teruggebracht worden. Nutriënten worden zo nog steeds gerecycled maar dan op het juiste moment voor de plant en snel omgezette organische stof wordt vergist en als methaan voor energietoepassingen ingezet. Ook is het winnen van eiwitten uit gewasresten een optie (zie hieronder). Cosun doet dit sinds kort met suikerbietblad (zie 3.4). De resten worden vergist en het digestaat wordt teruggebracht naar het land. Ook andere bedrijven, zoals Grassa ${ }^{6}$, werken aan eiwitwinning uit vers bladmateriaal.

\section{GFT}

Dit is een stroom die samengesteld is uit organisch materiaal van huishoudens waaronder keuken- en tuinafval. Nu wordt het vooral gecomposteerd eventueel nadat er biogas is gewonnen. Verder worden er ook specifieke delen uit gezeefd of afgescheiden zoals hout die weer ander toepassingen kunnen hebben.

\section{Snoei/rooi hout uit de fruitsector en boomkwekerij}

De huidige toepassingen zijn in $\mathrm{H} 2$ beschreven. Energieproductie is een belangrijke toepassing, net als voor andere houtstromen in Nederland. Toepassingen zullen naar verwachting opschuiven van warmte en elektriciteitsproductie nu, naar hoogwaardige warmte (hoge temperatuur) en transportbrandstoffen. Zie Figuur 6 hierboven voor een overzicht van opties voor de inzet van hout. Recent is er door Spijker et al (2020) een verkenning gedaan naar de mogelijkheden om dit soort hout hoogwaardiger toe te passen waarbij nog meer opties zijn benoemd. Verder is hier een categorisering van hoogwaardigheid van toepassingen gegeven en zijn kansen en belemmeringen besproken. Pyrolyse, een van de mogelijkheden om hout hoogwaardiger dan sec energieproductie te verwaarden, wordt hieronder besproken.

\footnotetext{
${ }_{5}^{4}$ https://www.nutrinorm.nl/nl-nl/Paginas/Organische-meststoffen-De-samenstelling-van-organische-meststoffen.aspx

${ }^{5}$ https://www.wur.nl/nl/Onderzoek-Resultaten/Onderzoeksprojecten-LNV/Expertisegebieden/kennisonline/AF-18047-Beterdan-vergisten.htm

${ }^{6}$ https://grassa.nl/en/about-grassa/
} 


\section{Hout uit (natuur)landschap}

Voor hout uit natuur en landschap geldt hetzelfde als voor snoei/rooihout

\section{Bermgras}

Bermgras komt vrij bij onderhoud van wegen en waterwegen. Het materiaal wordt vaak achtergelaten maar ook veel afgevoerd voor compostering. Bermen zullen sneller ophogen bij achterlaten van maaisel. Dit brengt extra kosten en hinder met zich mee als de bermen moeten worden afgeschraapt. Bermgras is vaak vervuild met zand en zwerfvuil. Hierdoor moet het vaak gezeefd worden om verder verwerkt te worden. Zie BVOR, 2020. Toepassingen met meer toegevoegde waarde zijn mogelijk als het materiaal schoon is. Bijvoorbeeld productie van vezels voor karton (Zie hieronder het Natuurvezel applicatiecentrum) of eventueel afscheiding van eiwit (zie hierboven Grassa) als de concentratie van het eiwit hoog genoeg is.

Verder is vergisting voor biogas een optie waarna het digestaat als bodemverbeteraar kan worden afgezet. Ook andere fermentaties om chemicaliën of biobrandstoffen te maken zijn mogelijk.

Bij compostering van GFT, bermgras en natuurgras worden verschillende soorten compost gemaakt maar het is ook mogelijk om fracties aft te scheiden die als brandstoffen (bijvoorbeeld houtchips of pellets) worden afgezet of als vezels voor bijvoorbeeld kartonproductie. Zie BVOR, 2020. Er zijn veel initiatieven om uit bepaalde fracties bijvoorbeeld via fermentatie chemicaliën en brandstoffen te maken. Verder kan thermische conversie een optie zijn. Zie bijvoorbeeld Torwash en Pyrolyse die hieronder worden besproken. Deze worden echter nog niet op commerciële schaal toegepast.

\section{Slootmaaisel}

Slootmaaisel wordt meestal op de kant neergelegd. Het bestaat uit planten en zand en slib. Alternatieve toepassingen lijken moeilijker dan voor bermmaaisel, door de vervuiling en heterogeniteit.

\section{Natuurgras}

Voor natuurgras gelden dezelfde opties als voor bermmaaisel. Het materiaal is meestal schoner dan bermmaaisel dus zijn ook inzet als veevoer, vergisting en vezeltoepassingen makkelijker mogelijk.

\section{VGI}

Reststromen uit de voedings- en genotmiddelenindustrie zijn divers qua omvang en samenstelling. Het is dus moeilijk om hier generieke toepassingen voor te benoemen. De totale omvang is vrij groot zodat een nadere analyse op zijn plaats is om te bepalen welke toepassingen interessant zijn voor welke stroom.

\section{Slib}

Slib van de voedings- en genotmiddelenindustrie (VGI) wordt opgedeeld in klassen: slib van afvalwaterbehandelingen ter plaatse, slib van wassen en schoonmaken en slib van wassen en schoonmaken, pellen, centrifugeren en scheiden.

Probleem is het hoge watergehalte. Meestal bestaat het verder uit organische stof en veel as (zand) en nutriënten (N, P. K). Vergisting is een logische toepassing. Als het slib niet vervuild is kan het ook, zo mogelijk na een vergisting, in de landbouw worden ingezet waar de nutriënten en organische stof een waarde hebben. 


\subsection{Nieuwe en innovatieve verwaardingsmethoden}

\section{Nieuwe en innovatieve verwaardingsmethoden}

Hieronder worden een aantal nieuwe en innovatieve verwaardingsmethoden gegeven die relevant zijn voor de provincie Zuid Holland. De stichting Circular Biobased Delta (CBBD) is zeer actief in de regio op dit gebied. CBBD is een Triple Helix organisatie waarin bedrijven, kennisinstellingen en overheden, o.a. de provincies Zuid-Holland, Zeeland en Noord-Brabant, actief samenwerken om de kansen te grijpen die de biobased economie het unieke en groeiende ecosysteem in de Delta regio biedt. De stichting heeft als missie de transitie richting vergroenen en verdienen te versnellen. Ze heeft een coördinerende rol richting samenwerkingspartners als applicatiecentra, labs, havens en innovatieve industrieparken. Zelf jaagt de stichting vier flagship programma's aan: Sugardelta, Redefinery, Biorizon en CHAPLIN (bio-asfalt).

Het is uiteindelijk van cruciaal belang dat de grondstof (biomassa)-markt combinatie een succesvolle en concurrerende waardeketen geeft:

\section{biomassa $\rightarrow$ verwerkingsproces $\rightarrow$ toepassing $\rightarrow$ markt}

Op deze manier gaat vergroenen samen met verdienen. Er zijn vele voorbeelden van de uitwerking van deze keten.

Het valt op dat in deze modellen conversietechnologieën zoals pyrolyse, vergassen, bioraffinage en fermentatie veelvuldig voor komen, naast het meer traditionele vergisten.

Hier volgen een aantal voorbeelden die in de provincie de aandacht hebben of goed in de context van de provincie zouden kunnen passen (deze lijst zou nog verder uitgebreid kunnen worden)

\section{- Autogenerative high pressure digestion (Bareau)}

Het bedrijf Bareau heeft deze methode van vergisting-onder-druk verder ontwikkeld en is bezig met het opschalen. Deze technologie levert biogas met een hoog methaangehalte dat gezuiverd onder druk direct in het gasnet kan worden geïnjecteerd. Dat is in het licht van de huidige $\mathrm{CO} 2$ doelen extra interessant. Dit is potentieel een goede verwerking van vooral mest of slib en co-producten zoals gewasresten.

\section{- Natuurvezel applicatiecentrum}

In het Natuurvezel Applicatie Centrum (NAC) wordt o.a. gewerkt aan het omzetten van lokale biomassa stromen zoals grassen en tuinbouwreststromen in producten zoals composieten, papier/karton of vezel versterkt beton. Omroep Flevoland heeft een rapportage gemaakt van een van de projecten: www.omroepflevoland.nl/nieuws/181870/experimenteren-metberenklauw-als-grondstof.

Het NAC kan met ervaring, apparatuur en kennis meewerken aan ontwikkeling, training, en advies voor concrete oplossingen, van idee tot product. Dit zou bijvoorbeeld toegepast kunnen worden voor natuurgrassen, agrarische reststromen (zoals uit de glastuinbouw) en allerlei maaisels.

\section{- Valorisatielab reststromen tuin en akkerbouw (VARTA)}

Het VARTA center op de Green Chemistry Campus te Bergen op Zoom werkt aan de ontwikkeling van oplossingen waarbij de inhoud stoffen uit reststromen gescheiden worden en omgezet in hoogwaardige producten. Denk aan zeer hoogwaardige oliën uit uienrestanten of het snoei afval van laurier struiken. Het kan hier om relatief kleine hoeveelheden gaan maar door de hoge toegevoegde waarde wordt toch een positieve business case bereikt. Dit zou bijvoorbeeld goed toegepast kunnen worden op diverse glastuinbouw rest stromen of bepaalde VGI stromen. 


\section{- Bioraffinaderijen}

In de biobased economie wordt een bioraffinaderij de nieuwe basis voor productie van brandstoffen en chemicaliën. Wereldwijd zijn de eerste demo installaties in bedrijf. Het bedrijf Biondoil $^{7}$ werkt aan de realisatie van een bioraffinaderij in het Rotterdamse havengebied. Het plan is om de grote benodigde hoeveelheden vezelachtig biomassa (lignocellulose, hout, stro etc.) per schip aan te voeren en om te zetten in bio-ethanol en andere producten. Wanneer de raffinaderij eenmaal draait is het natuurlijk ook denkbaar om voor een deel lokale biomassa aan te voeren indien deze aan de juiste specificaties voldoet en op prijs concurrerend is. Dit zou bijvoorbeeld toegepast kunnen worden op diverse houtige biomassa stromen uit natuurlandschap en van kwekers.

\section{- Biomassa marktplaats}

Om te stimuleren dat biomassa goed benut wordt helpt het om vraag en aanbod zo goed mogelijk op elkaar af te stemmen. Volwassen markten werken meestal niet met 1 op 1 relaties die risicovol zijn. Er is handel van meerdere aanbieders naar meerdere afnemers, hierdoor ontstaat ook een gezond concurrentieveld. Een biomassa marktplaats kan dit voor de biobased economie stimuleren, op www.biocontact.eu is een concreet voorbeeld hiervan te zien. De kracht hiervan is gerelateerd aan de gebruiksintensiteit, zeker in de regio als het om regionale biomassa gaat.

\section{- Eiwitten winnen uit grassen en loof}

Sommige grassen en loven zijn rijk aan eiwitten. O.a. Grassa en Cosun werken aan processen om deze eiwitten te winnen en als producten voor humane consumptie of veevoer in te zetten. Hierdoor zou de afhankelijkheid van geïmporteerde soja eiwit verminderd kunnen worden. Dit zou bijvoorbeeld toegepast kunnen worden op diverse groene agrarische stromen, eiwitrijke maaisels en ook waterplanten.

\section{- Pyrolyse van biomassa en recycle plastics}

In de regio wordt op meerdere plaatsen aan pyrolyse gewerkt, o.a. door het Pyrolyse cluster in Moerdijk, TNO (voormalig ECN) in Biorizon op de Green Chemistry Campus, Obbotec in Plant One. Pyrolyse is een thermisch/chemische verwerking waarbij biomassa of recycle plastics (soms ook in mengvorm) worden omgezet in pyrolyse olie, gas en char (kool) voor toepassing als brandstof, chemische grondstof en energie. Dit zou bijvoorbeeld toegepast kunnen worden op relatief laagwaardige mengsels van biomassa en uit gesorteerd afval (RDF; Refuse Derived Fuel).

\section{- $\quad$ Torwash van diverse soorten slib}

Speciaal voor de verwerking van relatief laagwaardige biomassa stromen met een hoog vocht gehalte heeft TNO/ECN het Torwash proces ontwikkeld. Zouten en andere mineralen worden uitgewassen en het ontwateren (van b.v. zuiveringsslib) wordt sterk verbetert. Als product ontstaat een korrel die geschikt is voor energieproductie. Dit zou bijvoorbeeld toegepast kunnen worden op zuiveringsslib of geschikte soorten industrieel slib.

\section{- $\quad$ Phario PHA plastic uit riool slib}

Het 'PHARIO' (PHA uit RIOolwater ${ }^{8}$ ) project produceert met bacteriën die op grote schaal het afvalwater zuiveren, en het afbreekbase bioplastic PHA (PolyHydroxyAlkanoaat). Dit bioplastic is een natuurlijke polyester. Toepassing kan zijn bv landbouw plastic, aquatische plastics en "controlled release" coating op kunstmest. Vijf waterschappen plannen een proefinstallatie in Dordrecht die in 2021 operationeel zou moeten zijn.

\footnotetext{
7 https://biondoil.eu/

${ }^{8}$ https://utilities.nl/waterschappen-bouwen-demo-installatie-phario/
} 


\section{$5 \quad$ Discussie en acties}

\subsection{Discussie}

Hierboven zijn biomassastromen beschreven in Zuid Holland, waarvoor een circulairdere aanwending gezocht zou kunnen worden. Het is belangrijk te beseffen dat we hier dus starten met materiaal waarbij de circulaire stappen Refuse, Rethink and Reduce (R 1 t/m R3) al gepasseerd zijn (zie Figuur 2). Voor heel veel van de (afval) stromen in Hoofdstuk 1 zou dus eigenlijk gekeken moeten worden of ze wel nodig zijn en of ze wellicht anders geproduceerd kunnen worden zodat er minder van geproduceerd zou worden. Denk aan verminderen van voedselafval.

In hoofdstuk 3 is er een concept beschreven om toepassingen van biomassa te beoordelen. Hierbij wordt gekeken naar de verschillende onderdelen van biomassa zoals vezels, eiwitten, nutriënten, suikers en zetmeel. Hierbij wordt redenerend vanuit het principe dat biomassa componenten functioneel en efficiënt ingezet moeten worden een hiërarchie van toepassingen beschreven. Daarnaast wordt er gekeken naar de herbruikbaarheid. Bij heel veel biomassatoepassingen kan de biomassa na gebruik gedeeltelijk weer benut worden. Met deze principes is het mogelijk de circulariteit van verschillende toepassingen van een zelfde soort biomassa te vergelijken. Dit systeem zal wel nog verder uitgewerkt en onderbouwd moeten worden. Met name voor toepassingen waar de functionaliteit van de biomassa niet geheel duidelijk is. Welke toepassingen beter zijn dan de andere is soms evident maar soms ook niet. Het is ook belangrijk dat de efficiëntie van de toepassing wordt meegerekend. Inefficiënt als veevoer inzetten tegen zeer efficiënt in energie omzetten. Hoe ga je daar mee om?

Behalve de circulaire indicatoren zijn er ook andere aspecten die minstens even relevant zijn zoals het broeikaseffect of effect op luchtkwaliteit van verschillende toepassingen. Verder is het ook belangrijk of er wel een business case te maken is. Als er geen markt is voor een product dan is het ook geen zinnige toepassing en als het te veel kost ook niet. Verder zullen in veel gevallen ook regels en normen toepassingen in de weg staan. Is het wenselijk om ze aan te passen?

Een voorbeeld is het verbod om slib als meststof toe te passen. Kan de zorg dat er vervuiling optreed op een andere manier ondervangen worden? Slib toepassingen als bodemverbeteraar is beter dan slib, met een heel hoog vochtgehalte, te verbranden. Vraag is dan ook hoe al deze criteria goed en consequent tegen elkaar af te wegen.

Veel van de stromen op de evaluatielijst zijn heterogeen/divers, wat toepassingen beperkt. Daarom wordt er vaak gezeefd bij composteerinrichtingen. Minder vervuiling leidt tot meer mogelijkheden om te verwaarden.

Mogelijk kunnen wegbermen anders aangelegd worden zodat het gemaaide gras minder vervuild raakt. Of kan er op een ander tijdstip geoogst worden wanneer er meer eiwit in zit waardoor het als veevoer kan dienen.

Veel van de huidige verwerkingsmethoden van de beoordeelde laagwaardige biomassa stromen zullen voorlopig wel blijven bestaan zoals composteren, vergisten en verbranden. Maar er zal een stap voor moeten komen, bijvoorbeeld om eiwit af te scheiden, of vezels voor toepassing in karton. Biomassa kan ook worden voorbehandeld om meer biogasopbrengst te realiseren of om de veevoer waarde te verhogen.

\subsection{Acties / Handelingsperspectief}

Uitgaande van de in kaart gebrachte biomassastromen kunnen we een aantal aanbevelingen formuleren die o.a. afgeleid zijn van het recente onderzoek van Spijker et al (2020) over de mogelijkheden om hout uit landschap hoogwaardig (= circulairder) af te zetten. 


\section{Uitwerken beoordelingssysteem om toepassingen van biomassa te beoordelen}

In hoofdstuk 3 staat een eerste uitwerking van een systeem om toepassingen specifiek op circulariteit en andere impacts te beoordelen. Dit systeem zou verder uitgewerkt moeten worden zodat het de onderliggende gedachte van circulariteit weergeeft en ook andere impact categorieën meeneemt. Dit zal een mix van harde cijfers en lokale voorkeuren zijn. Hierbij kan dan ook zichtbaar worden welke obstakels er in de implementeerbaarheid zijn. Hier kan de overheid waar relevant actie ondernemen om belemmeringen te slechten.

\section{Bij aanbesteding van landschapsonderhoud en afvalverwerking ook de circulariteit mee laten wegen.}

De meeste biomassastromen die in het rapport zijn besproken (H2) zijn afvalstromen die door gemeentes worden ingezameld en verwerkt of ze worden geproduceerd bij onderhoud van wegen of andere oppervlakken die onder controle van overheden vallen. Overheden besteden afvalverwerking, onderhoud van wegen, waterwegen en natuur aan en selecteren aannemers op kostprijs en impact. De wijze van oogsten, bewaren en transporteren bepaalt of bepaalde toepassingen mogelijk zijn. Als een aannemer beloond wordt voor circulaire afzet zal dat een stimulans zijn voor het circulair afzetten van de biomassa. De in Hoofdstuk 3 beschreven principes om circulariteit te beoordelen kunnen tot een methode worden uitgewerkt (zie 1) die het mogelijk maakt dit mee te wegen in aanbestedingen.

\section{Pilots uitvoeren om de systematiek om circulariteit te kwantificeren te testen}

$\mathrm{Na}$ het uitwerken van 1 en 2 is het aan te bevelen om het systeem in een aantal pilots uit te testen zodat op basis van de bevindingen succesvolle circulaire toepassingen van biomassa gestimuleerd kunnen worden. Eventueel zou CBBD hierin een actieve rol kunnen spelen.

\section{Slib toch voor bemesting inzetten?}

Veel van de biomassa in Zuid Holland is slib. Er gelden nu veelal regels die niet toestaan om dit slib voor de bodem als meststof in te zetten. Wordt er een andere afwegingen gemaakt worden als ciculariteit meegewogen wordt? Vaak wordt het slib gestort of gedroogd en/of ontwaterd en verbrand wat zeer inefficiënt is. De as wordt voor wegenbouw gebruikt. Zie de Boerderij (2020).

\section{Alleen vergiste mest laten aanvoeren van buiten het bedrijf}

Zuid-Holland heeft relatief veel akkerbouw en minder veeteelt en is een netto importeur van mest, met name uit Noord-Brabant. Dit levert geld op en mest helpt om de bodemkoolstof en het bodemleven op peil te houden. Zuid-Holland zou kunnen eisen dat er alleen vergiste en verwerkte mest wordt aangevoerd omdat dit een zelfde waarde voor de bodem heeft en broeikasgasuitstoot bespaart. De legaliteit hiervan hebben we niet bekeken, maar dit soort opties zijn het waard onderzocht te worden. Dit ligt duidelijk in het verlengde van de eerdere genoemde studie die OZHZ heeft verricht voor de Hoeksche Waard (de Bruin 2015).

\section{Biomassamarktplaats opzetten.}

Veel biomassa komt in kleine hoeveelheden vrij. Vraag en aanbod bij elkaar brengen kan er voor zorgen dat stromen die geschikt zijn voor hoogwaardigere toepassingen ook hoogwaardig zo ingezet kunnen worden. Een goede categorisering kan hierbij helpen. Bijvoorbeeld 500 ton verse bermgras geschikt voor "vergisting en voor ruwvoer". Onderzoek naar eerdere initiatieven in het licht van circulariteit zou zinvol kunnen zijn.

\section{Sorteer voor op hoogwaardige toepassingen.}

Veel technologieën om biomassa hoogwaardiger in te zetten zijn nog niet op de markt. Zie bijvoorbeeld eiwit uit groene stromen afscheiden. Het heeft wel zin om nu al te zorgen dat groene reststromen hiervoor geschikt zijn, door schoner te oogsten en ze in te zetten voor vergisting. En om de voor Zuid-Holland meest relevante te ondersteunen in hun ontwikkeling met bijvoorbeeld beleid, tijdelijke regelgeving, experimenteergebieden, financiering van onderzoek en ontwikkeling. Pyrolyseolie wordt nog niet in jetfuel omgezet maar gebruikt voor verwarming. Welke biomassastromen kunnen voor pyrolyse geschikt gemaakt worden zodat het wel geschikt wordt voor hoogwaardige brandstoffen en uiteindelijk iets als jetfuel? 


\section{Literatuur}

Boerderij (2020). 'Landbouw is per definitie niet circulair' www.boerderij.nl/Home/Achtergrond/2019/2/Landbouw-is-per-definitie-niet-circulair-395600E/ (6 juni 2020 geconsulteerd).

de Bruin. H. 2015. Onderzoek naar de haalbaarheid van de inzet van mest en gebiedseigen Biomassa voor Energieopwekking in de Hoeksche Waard. Omgevingsdienst Zuid-Holland Zuid.

BVOR. 2020. MARKTCIJFERS GRONDSTOFFEN UIT ORGANISCHE RESTSTROMEN IN 2019.

CE-Delft. 2020. Bio-Scope. Toepassingen en beschikbaarheid van duurzame biomassa. februari 2020. Publicatienummer: 20.190186.017

Elbersen, B., R. Bugter, K. Meesters, I. Vural Gursel, W. Elbersen, M. van Leeuwen, P. Mostert, M. de Vries, R. Jongschaap, G. Piet, I. van der Fels Klerx (2020) Monitoring and impact evaluation system. Circularity at different scales. KB-1-1B-1 project 2019 progress report.

Elbersen Wolter, Siemen van Berkum, Just Dengerink, Anton Schultze-Jena (2020). Circular valorisation of agri-residues. How to make better use of agricultural residues. Interim Report by Wageningen Food \& Biobased Research and Wageningen Economic Research. Commissioned by the Dutch Ministry of Agriculture, Nature and Food Quality. Wageningen, January 2020.

Elbersen Wolter, Anjo de Jong en Joop Spijker. 2017. Notitie: Kort onderzoek naar het poorttarief (gate-fee) voor maaisel-verwerking bij composteerbedrijven in Nederland. Met focus op maaisel van Rijkswaterstaat. Wageningen Food \& Biobased Research.

Rijkers, Jasper (2020). Biomassa Zuid-Holland. Een inventarisatie naar de verschillende biomassa reststromen in Zuid-Holland. Student rapport Avans Hogeschool.

Min I\&M (2019). Uitvoeringsprogramma Circulaire Economie 2019-2023.

PBL (2016). VOEDSEL VOOR DE CIRCULAIRE ECONOMIE. PBL Policy Brief. PBL Planbureau voor de Leefomgeving. Den Haag, 2016. PBL-publicatienummer: 2145

PBL (2018). Circular economy: what we want to know and can measure. Framework and baseline assessment for monitoring the progress of the circular economy in the Netherlands. PBL Netherlands Environmental Assessment Agency. The Hague, 2018. PBL publication number: 3217

Spijker, Joop, Wolter Elbersen, Iris Vural Gursel, Bas Lerink. 2020. Marktverkenning biomassareststromen hout uit landschap. Wageningen Environmental Research. Rapport 2991. 42 blz. (https://research.wur.nl/en/publications/marktverkenning-biomassareststromen-hout-uitlandschap )

https://www.nutrinorm.nl/nl-nl/Paginas/Organische-meststoffen-De-samenstelling-van-organischemeststoffen.aspx

https://www.rvo.nl/subsidies-regelingen/projecten/autogenerative-high-pressure-digestion

https://www.wur.nl/en/show/Autogenerative-High-Pressure-Digestion.htm

https://bareau.nl/wp-content/uploads/2019/01/AHPD-Position-Paper-English.pdf

https://www.cosunbeetcompany.nl/toepassingen/voeding/proteine

https://www.nieuweoogst.nl/nieuws/2019/10/11/eiwit-uit-bietenblad-als-voedingsingredient 


\section{Bijlage 1. PowerPoint presentatie Workshop 11 mei 2020}

\section{Circulair verwaarden biomassa in Zuid Holland} Focus vandaag: Maaisels en snoeihout
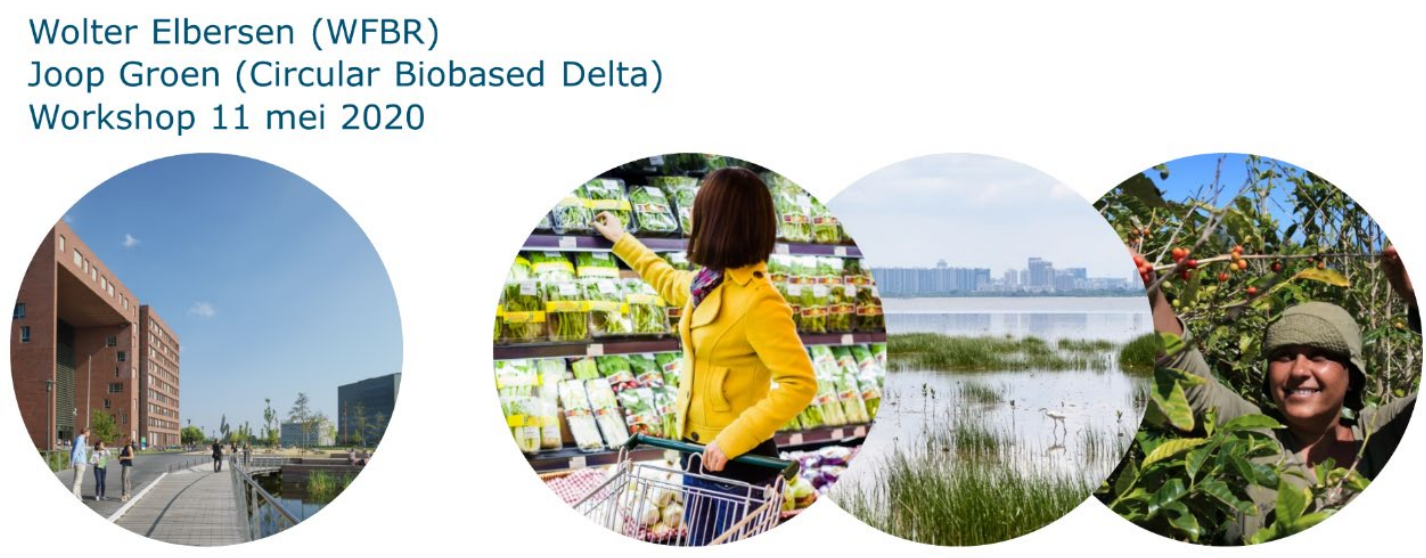

D. WAGENINGEN

\section{Agenda}

- In Memoriam Aldert vd Kooij

- Introductie circulair verwaarden:

- R trappen en verwaardingspiramide

- Hoe is biomassa anders? Biomassa is samengesteld (vezel, eiwit, vetten, nutriënten)

- Verwaardingstrappen gericht op benutten en behouden van de functionaliteit.

- Biomassa reststromen in Zuid Holland

- Wat is het?

- Wat doen we nu ermee?

- Verwaardingsrichtingen plus voorbeelden: Kansen en Belemmeringen

WAGENINGEN 


\section{In memoriam: Aldert van der Kooij}

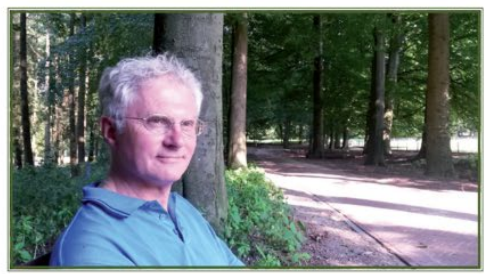

"Veni, vidi, foetsie"

Aldert van der Kooij, april 2020
Leendert Arie van der Kooij

Hillegom, 25 mei $1957 \quad$ Ede, 28 april 2020

Ondanks zijn moeder
thuis overleden.

Een altijd positieve, energieke en technisch zeer vaardige collega is ons veel te vroeg ontvallen, we zullen hem missen en nooit vergeten!

Stichting Biobased Delta

\section{De waardepiramide en de R-ladder}

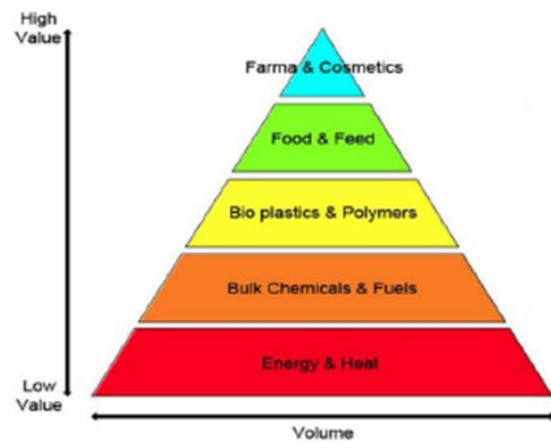

WAGENINGEN
R-ladder met strategieën van circularitei

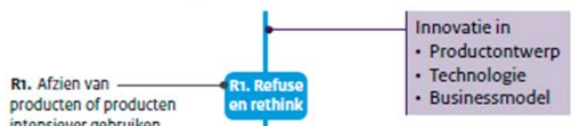

5: hek gebruiken van reststromen voor voedsel, veevoer, materiaal of meststof/ compost, bijvoorbeeld door het gebruiken van broodresten om bier te brouwen.

R5.1 - Reststroom gebruiken als voedsel of diervoeder

R5.2 - Reststroom gebruiken als grondstoffen voor de industrie

R5.3 - Reststroom gebruiken als meststof of compost

R6: het gebruiken van reststromen voor energie, zoals vergisters en palletkachels die biotische reststromen (voornamelijk) omzetten in energie. Vergisters produceren ook meststoffen (recycling), maar omdat ze ontworpen zijn voor energieproductie hebben we ze ingedeeld bij recover.

Bij R5 en R6 is het van belang dat mineralen worden teruggebracht in de landbouw (als meststof of diervoeder) nadat de organische stoffen uit het product zijn gebruikt of omgezet.
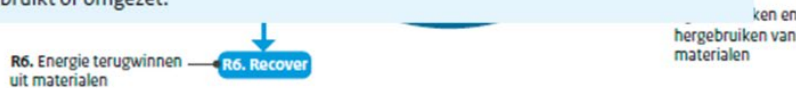

Bron: PBL

\section{Optimaal verwaarden van biomassa door functionaliteit efficient te benutten en herbenutten}

Biomassa bestaat uit onderdelen:

- Vezels (lignine, cellulose, hemicellulose)

- Eiwitten

- Suikers

- Zetmeel

- Vetten

- Mineralen (N, P, K)

- Specifieke moleculen (pectine, antioxidanten kleurstoffen, geurstoffen, etc.)

\section{2 a 60 ton droge stof per hectare}

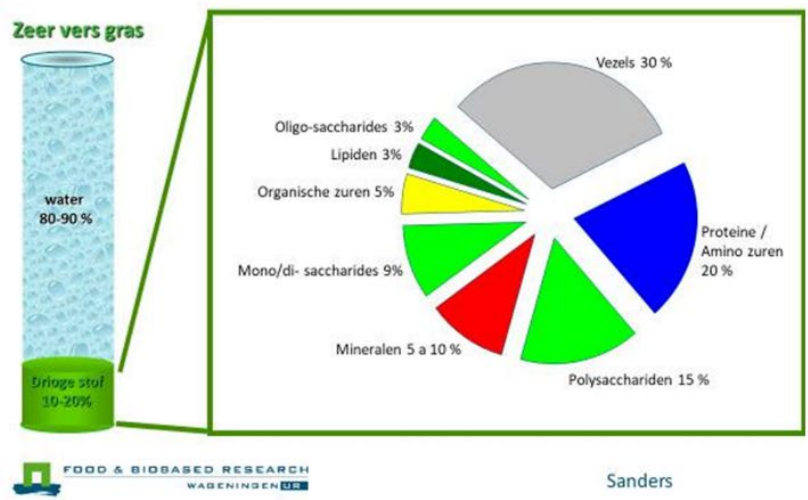




\section{Model circulair verwaarden}

Beoordelen op

-Circulariteit

-Socio-economisch

-Duurzaamheid

/Ecologie

-Implementeerbaarheid

WAGENINGEN

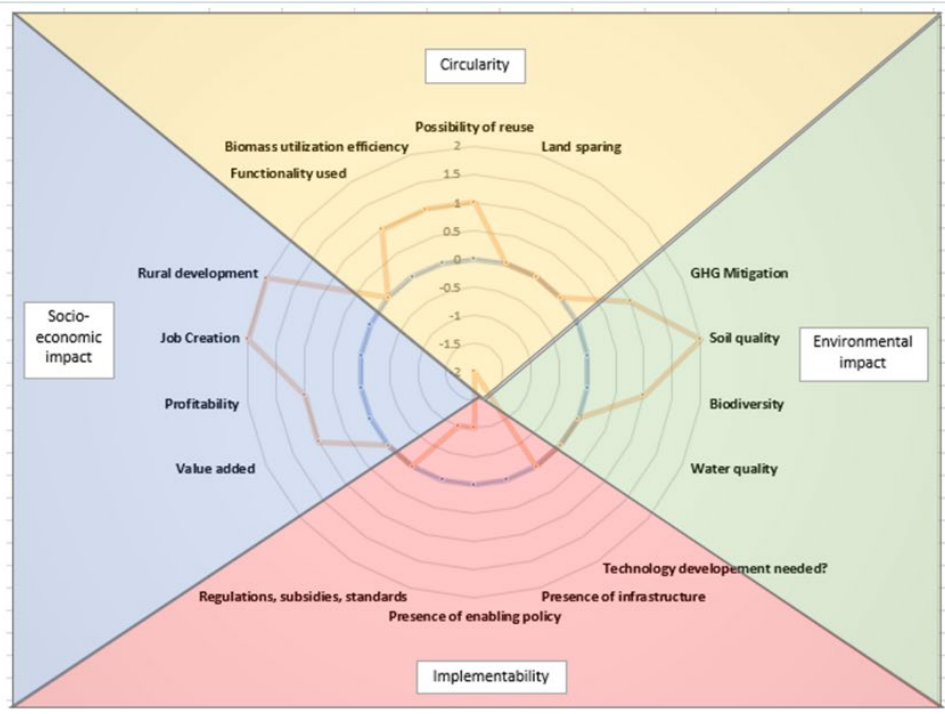

\section{Verwaardingstrappen voor vezel en eiwit}

\section{Vezel}

4. Vezel benutten met maximale functionaliteit (meubels, touw, klompen)

3. Vezel benutten na gedeeltelijke afbraak: (Papier/ pulp)

2. Vezel afgebroken tot monomeren / moleculen. Suikers, pyrolyseolie, etc

1. Vezel voor energie en warmte

0 . Vezel afgebroken en energie niet benut

WAGENINGEN
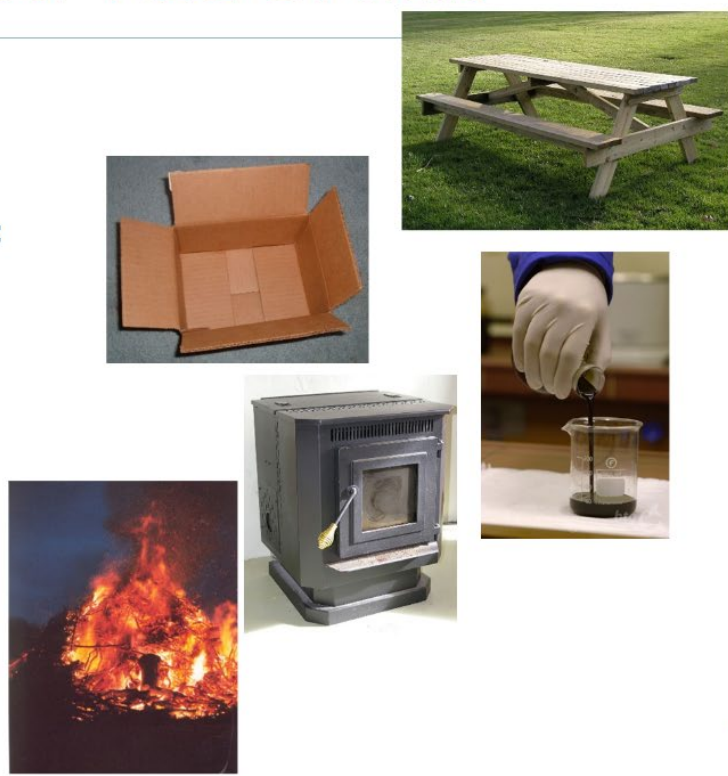

\section{Verwaardingstrappen voor eiwit}

\section{Eiwit}

4. Eiwit voor voedsel

3. Eiwit voor voer

2. Eiwit voor non-food en bemesting

1. Eiwit voor energie

0 . Eiwit afgebroken en niet benut.
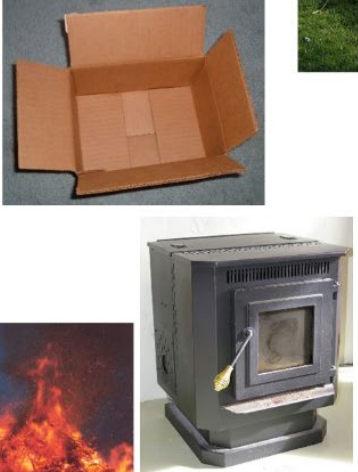


\section{Scoren: 1 voorbeeld voor vezels}

\begin{tabular}{|l|c|c|c|c|c|}
\hline Toepassing & $\begin{array}{l}\text { Functionali- } \\
\text { teit (0 tot } \mathbf{4})\end{array}$ & $\begin{array}{l}\text { Materiaal- } \\
\text { efficiëntie }\end{array}$ & $\begin{array}{l}\text { Energie- } \\
\text { efficiëntie }\end{array}$ & Score & $\begin{array}{l}\text { Herbruikbaar } \\
\text { heid? }\end{array}$ \\
\hline $\begin{array}{l}\text { Papierpulp uit hout } \\
(\mathbf{7 0} \%) \text {; }\end{array}$ & 3 & $70 \%$ & & 3 \\
\hline $\begin{array}{l}\text { Resten }(\mathbf{3 0} \%) \text { als } \\
\text { energiehout in industriële } \\
\text { kachel met } \mathbf{8 0} \% \text { - } \\
\text { efficiëntie }\end{array}$ & 1 & $30 \%$ & $80 \%$ & 2,3 & 0 \\
\hline
\end{tabular}

\section{Biomassa reststromen in Zuid Holland}

Inventarisatie door Avans Hogeschool

\begin{tabular}{|c|c|c|c|c|c|}
\hline Stromen: & $\begin{array}{l}\text { Hoeveelheid } \\
\text { (kton/jaar) }\end{array}$ & Kwaliteit & Huidig & Probleem & Toekomst \\
\hline Snoei/rooi hout uit de fruitsector en boomkwekerij & 16.4 & $\begin{array}{l}\text { Houtige en groene biomassa (tak en } \\
\text { top) }\end{array}$ & $\begin{array}{l}\text { Hout chips, energie, } \\
\text { producten }\end{array}$ & $\begin{array}{l}\text { Kwaliteit/kwantiteit, } \\
\text { aansluiting op vraag }\end{array}$ & $\begin{array}{l}\text { Biomassa hubs voor } \\
\text { kwantiteit en kwaliteit }\end{array}$ \\
\hline Hout uit (natuur)landschap & 40 & $\begin{array}{l}\text { Houtige biomassa (stronken, takken } \\
\text { etc.) }\end{array}$ & $\begin{array}{l}\text { Hout chips, energie, } \\
\text { producten }\end{array}$ & $\begin{array}{l}\text { Kwaliteit/kwantiteit, } \\
\text { aansluiting op vraag }\end{array}$ & $\begin{array}{l}\text { Bouw, vezel, monomeer, } \\
\text { brandstof, energie }\end{array}$ \\
\hline Bermgras & 46.1 & Bermgras, contaminatie & Achterlaten, composteren & $\begin{array}{l}\text { Ophoging, contaminatie, } \\
\text { kosten }\end{array}$ & $\begin{array}{l}\text { Biomassa hubs voor } \\
\text { kwantiteit en kwaliteit }\end{array}$ \\
\hline Slootmaaisel & 94.9 & Waterplanten, zand, klei & Achterlaten & $\begin{array}{l}\text { Ophoging, contaminatie, } \\
\text { kost geld }\end{array}$ & $\begin{array}{l}\text { Vezel toepassingen, } \\
\text { mineralen, eiwitten, } \\
\text { vergisten }\end{array}$ \\
\hline Natuurgras & ? & Gemaaid natuurgras & $\begin{array}{l}\text { Regionaal sterk } \\
\text { verschillend }\end{array}$ & & \\
\hline
\end{tabular}

- Focus vandaag: maaisels en snoeihout (circulair terreinbeheer)

- Vele mogelijkheden voor betere verwaarding

- Innovatie en samenwerking spelen sleutelrol, dit is een nieuw werkveld

WAGENINGEN

NIVERITY S RESEARC

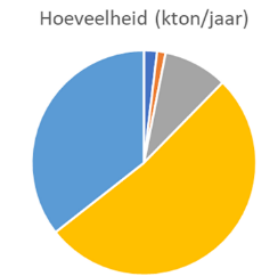

- Maisels a Snoeihout = Overis

\section{Het potentieel van locale biomassa}

- Potentieel van lokale biomassa

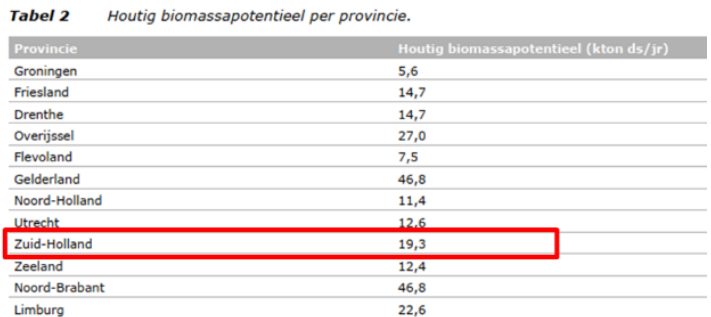

- Kwaliteit (schoon, homogeen, ...)

- Kwantiteit (economy of scale)

- Betrouwbaar (korte/lange termijn)

- Concurrerende prijs

Vezeltoepassingen - Pyrolyse olie - Vergisten - Composteren

Van snoeien en maaien naar telen en oogsten! 


\section{Voorbeelden van benutten biomassa}

Kansen

Vezel applicaties in papier, karton, composiet. Advies, training, ontwikkeling, faciliteiten. Van idee tot product

Belemmeringen

Afval als product zien: kwaliteit, schoon, kwantiteit, betrouwbaar

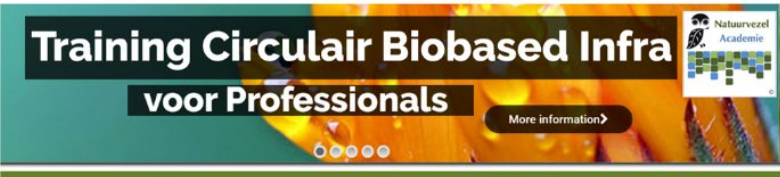

Economisch, schaal grootte

Wetgeving
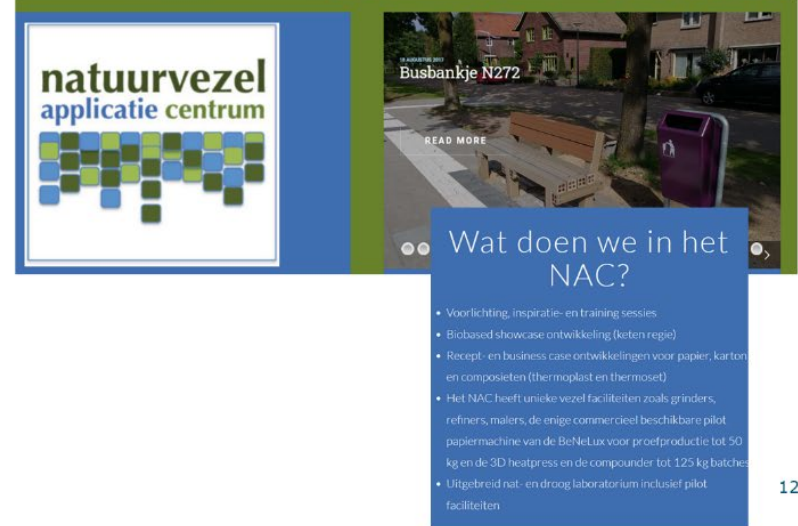

\section{Eiwit afscheiden uit maaisels}

- O.a. Suiker Unie en Grassa

- Verminderen Soja eiwit import

- Eiwit concentraten beschikbaar voor kippen en varkens (efficienter dan koeien)

- Potentieel hoge waarde!

\section{BOERDERIJ

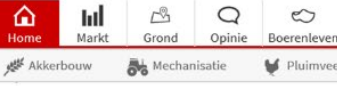

\section{Grassa de markt op}

Grassa gaat commercieel en brengt grasraffinage naar de markt. In Oenkerk (Frl.) toont directeur Martijn Wagener van de kersverse bedrijf stapsgewijs het raffinageproces dat vezels en eiwit oplevert. In september gaat Grassa met een mobiele
installatie de boer op.

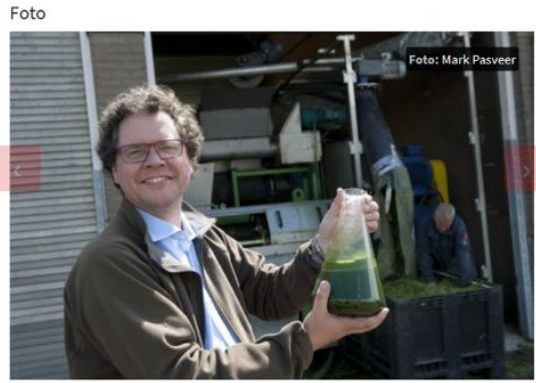

\section{Voorbeelden: Bioraffinage Biondoil}

Kansen

Biobrandstoffen en -chemicalien uit lignocellulose

Biomassa via havens maar ook lokaal?

Belemmeringen

Businesscase is uitdagend

Nieuwe technologieen, risico's

Wetgeving en subsidies

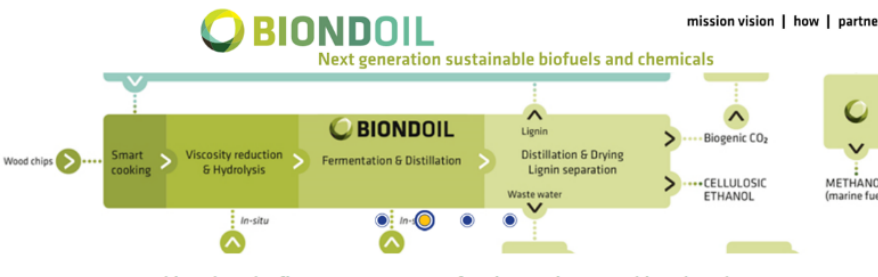

bio-ethanol refinery process: steam fraction, main output bio-ethanol Biondoil develops Bio-Refinery concepts on industrial scale exploring green-field and brown field apportunities. The cornerstone of our projects is the conversion of lignocelllulose biomass into bio-ethanol. opportunitites. The cornerstone of our projects is the conversion of lignocellulose biomass into bio-ethanol
Currently the business driver in Europe is the RED2 renewable energy directive encouraging oil companies to mix biogenetic material in their fuels.

There are two proven technologies to produce bio-ethanol on a substantial scale, basically using different pre-treatment systems:

Pre-treatment based on steam explosion

- Pre-treatment consist on the smart cooking of biomass using only water and steam (no chemicals are added), operating with optimized conditions and temperature, pressure and residence time. the stage creates large volume of water residue wh his denes and reerled. 


\section{Voorbeelden: Biomassa marktplaats}

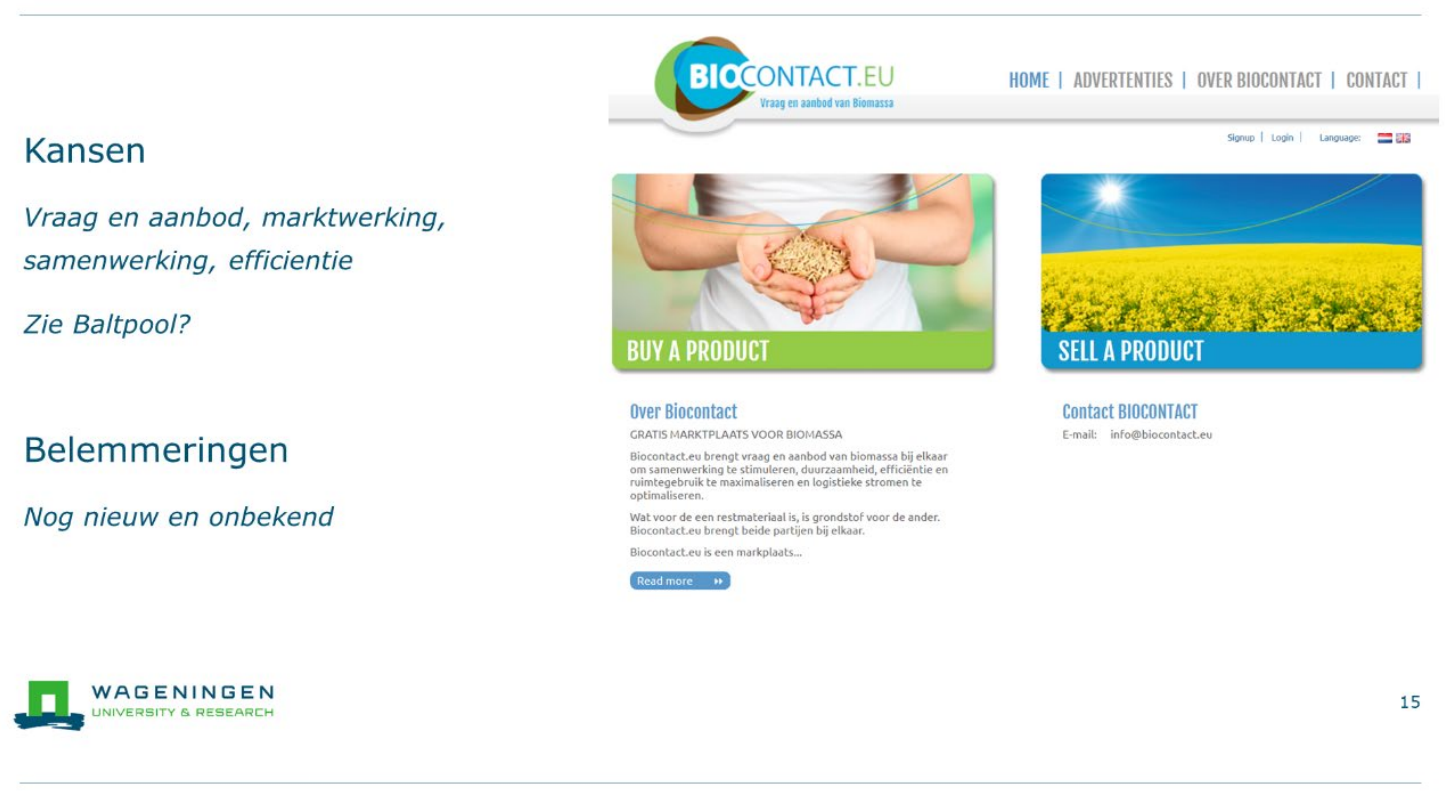

wolter.elbersen@wur.nl joop@viridebio.eu

WAGENINGEN

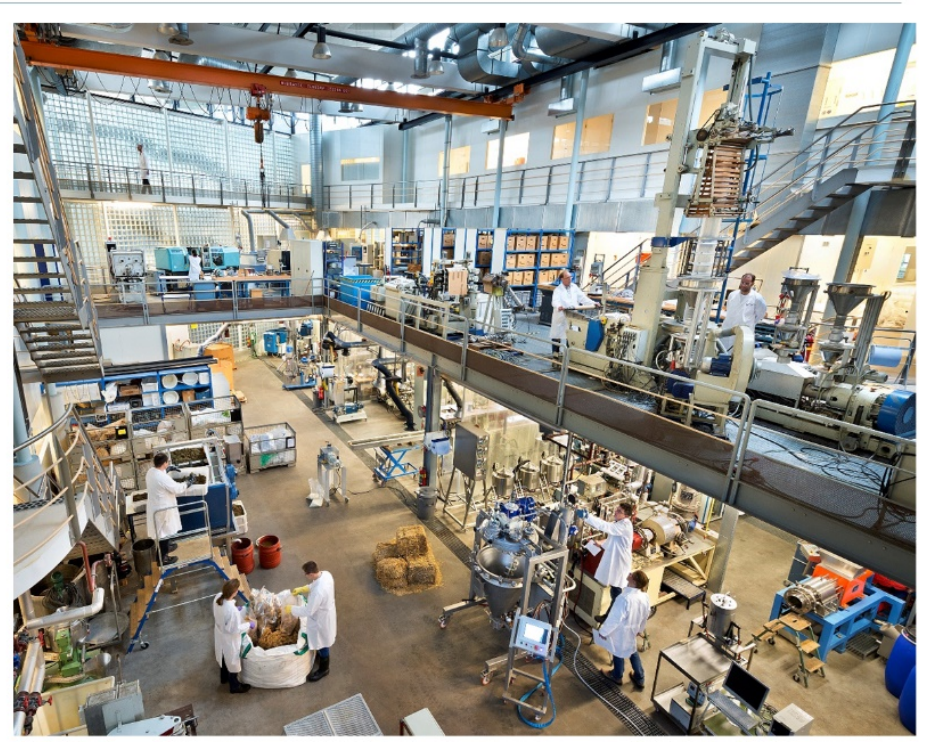

